\title{
10. CRETACEOUS FORAMINIFERS OF HOLE 530A, LEG 75, DEEP SEA DRILLING PROJECT ${ }^{1}$
}

\author{
C. L. McNulty, University of Texas at Arlington, Texas
}

\begin{abstract}
Hole 530A of Leg 75 is located in the southeastern corner of the Angola Basin of the South Atlantic $\left(19^{\circ} 11.26^{\prime}\right.$ S; $\left.9^{\circ} 23.15^{\prime} \mathrm{E}\right)$, on the abyssal seafloor ( $4629 \mathrm{~m}$ depth), close to the Walvis Ridge and near its junction with the continental margin. The hole penetrated $503 \mathrm{~m}$ of Cretaceous (Maestrichtian to Albian) and bottomed in basalt at $1121 \mathrm{~m}$. No other hole of Leg 75 was drilled below the Neogene.

Most of the $10-\mathrm{cm}^{3}$ samples from Hole $530 \mathrm{~A}$ were barren of foraminifers. Most of the foraminiferal populations recovered were barren of planktonic specimens. Consequently, no correlation with established planktonic biozones was possible, and correlation with European stages was limited to Maestrichtian-Campanian, Santonian-Coniacian, ?lower Turonian, and Albian.

Most of the benthic species were interpreted to be displaced-not reworked nor redrilled cavings. Recognition of the displaced faunas helped in recognizing indigenous benthic faunas and in interpreting their paleodepth and provincial implications. Displaced faunas have temporal and paleogeographical value but not paleobathymetric value.

The prevalent general properties at Site $\mathbf{5 3 0}$ of sparsity of specimens, rarity of planktonic specimens, low taxonomic diversity of indigenous benthic faunas, and etched, worn, and broken specimens combined to indicate deposition well below the lysocline and near to, if not below, the carbonate compensation depth (CCD), or in the abyssal realm, during most of the Maestrichtian to Albian. Such a depositional environment is also implied by the primitive, quartzose, agglutinated faunas from noncalcareous red and green claystones, which occur with increasing prominence from the lower part of the Maestrichtian-Campanian interval to the bottom of the sedimentary section. The prominence, persistence, and physical condition of the displaced faunas suggest transport by a submarine fan system at some distance from the continental margin.

The faunas of Hole 530A resemble those of other paleoabyssal sites of the South Atlantic and Indian oceans and belong to the Austral Bioprovince. Latitudinal and provincial properties seem to diminish with depth, and the Albian indigenous benthic fauna is cosmopolitan. It is quite different from the Albian planktonic fauna of Hole 530A, which is definitely midlatitudinal and Austral, and from the Albian fauna reported from nearby Sites 363 and 364 .

The principal event of the sedimentary record is a medial Cretaceous lacuna, which includes most of the Turonian and Cenomanian and some of the Albian. Such a lacuna is widespread in DSDP sites of the southern hemisphere. Possible hiatuses occur at the base of the Maestrichtian-Campanian and at the base of the Santonian-Coniacian intervals.
\end{abstract}

\section{INTRODUCTION}

Site 530 is located in the southeastern corner of the Angola Basin of the South Atlantic Ocean $\left(19^{\circ} 11.26^{\prime} \mathrm{S}\right.$; $\left.9^{\circ} 23.15^{\prime} \mathrm{E}\right)$, on the abyssal floor ( $4629 \mathrm{~m}$ depth), close to the base of the Walvis Ridge and near to its junction with the continental margin (Fig. 1). After one core was taken, the first hole was abandoned because of a mechanical problem. The second hole, Hole 530A, terminated in basalt at $1121 \mathrm{~m}$ sub-bottom. Hole 530A penetrated $503 \mathrm{~m}$ of Cretaceous, which was divided into four lithologic units (Fig. 2).

The recovery of foraminifers from Cretaceous samples $\left(10 \mathrm{~cm}^{3}\right.$ volume) of Hole $530 \mathrm{~A}$ was poor. About $75 \%$ of all washed residues yielded few or no specimens. Of the residues with $1 \%$ or more foraminiferal specimens, about $75 \%$ were totally or dominantly benthic forms, except those approximately from the horizons of Cores 79,88 , and 94 . About $75 \%$ of the total benthic fauna of a faunule or of a chronostratigraphic interval is not recurrent. In other words, most benthic species occur in one or two samples only. Moreover, they are typically represented by only a few specimens in the sample of occurrence. Such species were considered to be displaced

\footnotetext{
${ }^{1}$ Hay, W. W., Sibuet, J.-C., et al., Init. Repts. DSDP, 75: Washington (U.S. Govt. Printing Office).
}

and were excluded from the recurrent and presumably indigenous benthic faunas. They are not included in the faunal lists of the chronostratigraphic intervals discussed below, but are presented separately in Table 1 .

In addition to the sparsity of all species and the persistent recurrence of so few species, foraminiferal populations are characterized by conspicuously poor preservation, because of dissolution, abrasion, and distortion. Consequently, it has been impossible to obtain satisfactory photomicrographs, although numerous attempts were made. Camera lucida drawings have been made to supplement photomicrographs of the more important benthic species, but photographic documentation of the dissolved and fragmentary planktonic and displaced benthic species, and of the fragmentary and distorted, quartzose, agglutinated species are not included in this chapter.

Because of the rarity of planktonic species in samples other than those from Cores 79,88 , and 94 , established foraminiferal planktonic biozones could not be recognized (Table 2). The chronostratigraphic intervals employed (Fig. 2), namely, Maestrichtian-Campanian, Santonian-Coniacian, ?lower Turonian, and Albian, are based upon both the few, rare, and erratic planktonic species and a small number of long-ranging recurrent benthic species (Tables 3, 4). As a result, the boundaries of intervals are questionable, and their differences from 


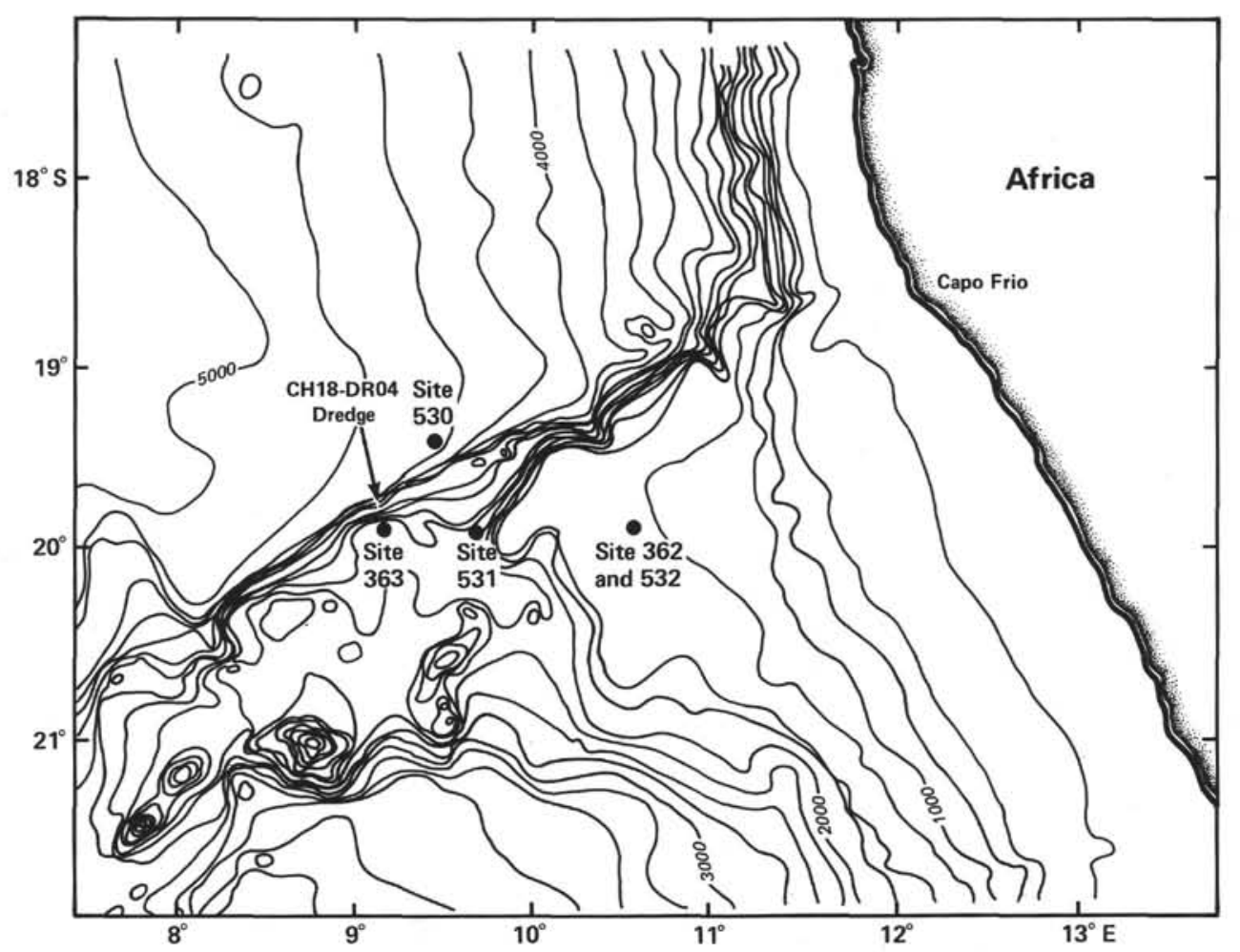

Figure 1. Location map for Site 530, DSDP Leg 75.

those based on nannofossils, as reported elsewhere in this volume, are also questionable.

\section{MAESTRICHTIAN-CAMPANIAN}

This interval extends from Core 50, Section 2, 10-14 cm through Core 80.

Neither the Tertiary/Cretaceous nor the Campanian/ Santonian boundary is well documented by foraminifers. Globotruncanids occur above Sample 50-2, 10-14 $\mathrm{cm}$, and Tertiary planktonic species occur as low as Core 62. Presumably the latter are cavings, although Tertiary specimens are common in residues as low as Core 57. The apparent sharpness of the base of this interval is questionable because of the lack of satisfactory samples immediately below the boundary. The correlation is based for the most part on very poorly preserved, rare, and infrequent globotruncanids and a restricted, also poorly preserved, but relatively persistent Paleogene to Campanian benthic assemblage.

In the interval from Core 50-2, 10-14 cm to Core 61 (lithologic Units $5 \mathrm{a}$ and $5 \mathrm{~b}$ ), one or two broken and eroded specimens of Abathomphalus mayaroensis Bolli, Globotruncana gagnebini Tilev, G. contusa (Cushman), G. fornicata Plummer, G. arca Cushman, Pseudoguembelina palpebra Brönnimann and Brown, Pseudotextularia difformis (Kikoine), and Rugoglobigerina sp. were found in residues of four samples. In the interval of Core 61 to Core 71 (Unit 5c), Globotruncana fornicata, G. linneiana (d'Orbigny), and Rugoglobigerina sp. occur with similar rarity. The volcanogenic interval of Core 71 to Core 75 (Unit 6) yielded no planktonic foraminifers, but the interval from Core 76 through Core 80 (upper Unit 7) provided more planktonic species than any other interval of the hole.

The planktonic fauna of Cores $\mathbf{7 6}$ through $\mathbf{8 0}$ is distinguished by simple and early globotruncanids, such as $G$. arca, G. fornicata, G. linneiana, and G. ventricosa White, by terminal marginotruncanids, including Marginotruncana (Dicarinella) asymetrica (Sigal) and $M$. sinuosa Porthault, by Planoglobulina glabretta (Cushman), and by rare, infrequent, other species, including Globigerinelloides asperus (Ehrenberg). Reworked specimens of Hedbergella planispira (Tappan), Praeglobotruncana stephani (Gandolfi), P. delrioensis (Plummer), and Rotalipora apeninnica (Renz) are common, especially in Core 79. Despite its deficiencies of preservation and diversity, the assemblage is indicative of the lower Campanian and provides this interval with the best correlation in the hole.

The persistent, recurrent (indigenous) species for the Maestrichtian-Campanian interval include Aragonia ouezzanensis (Rey), Dorothia trochoides (Marsson), Gyroidina diversus (Belford), Lenticulina velascoensis White, Nuttallides sp., N. truempyi (Nuttall), Nuttallinella? florealis (Cushman), N.? spinea (Cushman), Pullenia coryelli White, Reussella szajnochae (Grzybowski), Spiroplectammina dentata (Alth), and Valvulineria? whitei (Martin).

\section{SANTONIAN-CONIACIAN}

The upper part of this interval (Cores 81 through 86) is composed of red and green claystones and vari-colored turbiditic siltstones and sandstones, which appear to be a continuation of and are included in lithologic 


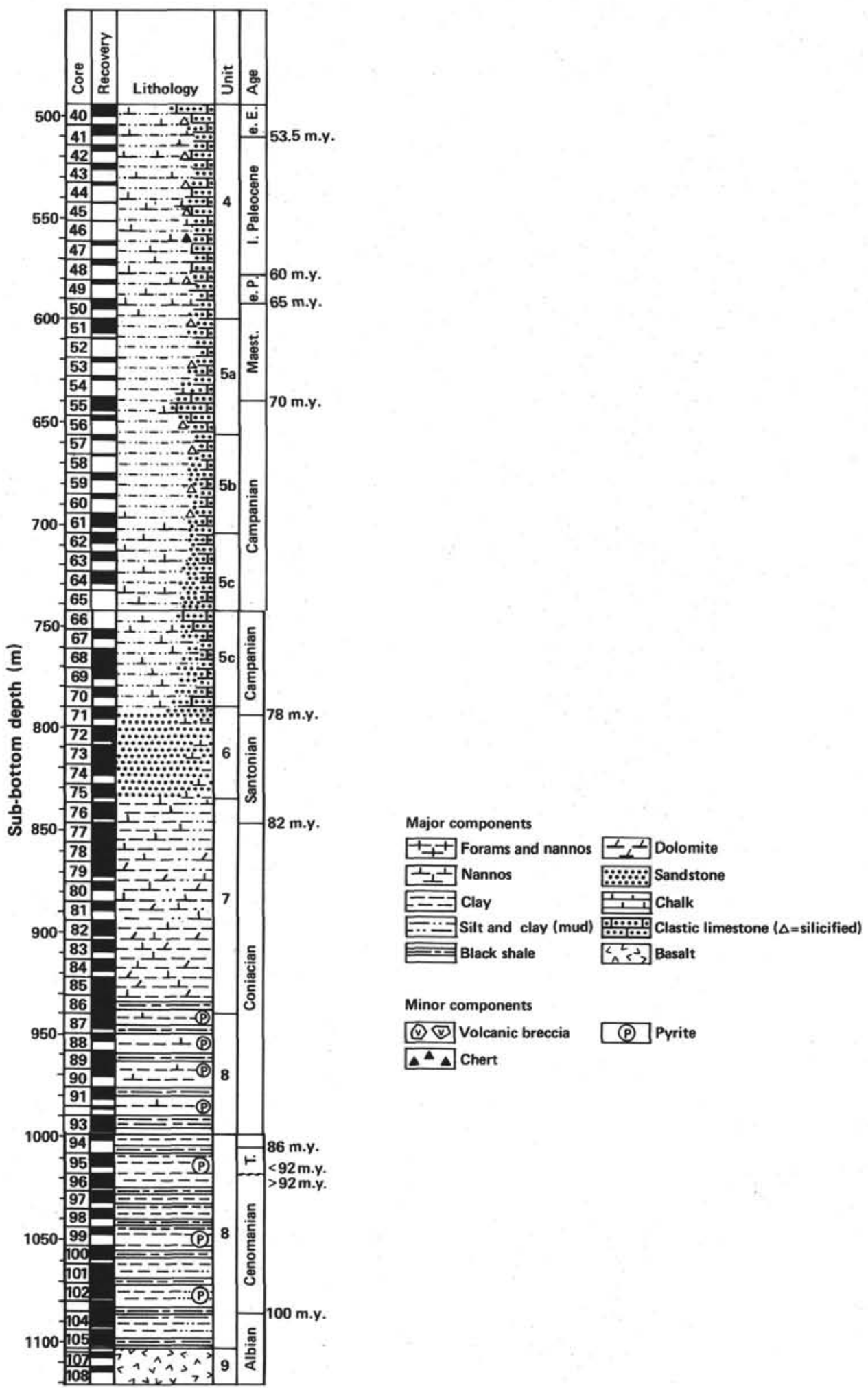

Figure 2. Columnar section showing lithologic units for Hole 530A, DSDP Leg 75. (Revisions of stratigraphic ages are given in Steinmetz et al., this volume.)

Unit 7. However, their foraminiferal content differs from that of the upper part of Unit 7 (Cores 76 through 80 ). First, the red and green claystones yield a sparse fauna of agglutinated benthic species like those that were reported by Krasheninnikov $(1973,1974)$ from sim- ilar lithology. Second, planktonic specimens are rare, except for one sample from Core 86, Section 3, 47-49 $\mathrm{cm}$, at the bottom of Unit 7, where they are poorly preserved and may be displaced. Third, the benthic fauna changes from upper to lower Senonian forms. 
Table 1. Displaced benthic species, Hole 530A.

Maestrichtian-Campanian

Allomorphina cretacea Reuss

Bandyella beckmanni Proto Decima and Bolli

Bolivina watersi Cushman

Bulimina reussi Morrow

Bulimina trinitatensis Cushman and Jarvis

Buliminella carseyae Plummer

Charletonia spp.

Clavulinoides disjuncta (Cushman)

Clavulinoides trilatera (Cushman)

?Conorbina spp.

Conorboides haidingeri (d'Orbigny)

Coryphostoma incrassata (Reuss)

Dorothia retusa (Cushman)

Ellipsodimorphina subtuberosa Liebus?

Ellipsoidella divergens Storm

Ellipsopolymorphina velascoensis (Cushman)

Fissurina sp.

Frondicularia striatula Reuss

Gavelinella cayeuxi mangshlakensis (Vassilenko)

Globorotalites micheliniana (d'Orbigny)?

Globulina lacrima Reuss

Globulina prisca Reuss

Marssonella crassa (Marsson)?

Neoflabellina sp. aff. N. numismalis (Wedekind) Beckmann Osangularia velascoensis (Cushman)

Pleurostomella spp.

Pseudoclavulina amorpha (Cushman)

Pseudonodosaria manifesta (Reuss)

Pullenia americana Cushman

Pullenia cretacea Cushman

Pullenia puentepiedraensis Galloway and Morrey

Quadrimorphina velascoensis (Cushman)

Spiroplectammina grzybowski Frizzell

Stensioina pommerana Brotzen

Valvulineria americana (Carsey)?

Santonian-Coniacian

Allomorphina cretacea Reuss

Bandyella greatvalleyensis (Trujillo)

Dentalina cylindroides Reuss

Dentalina gracilis d'Orbigny

Conorbina cretacea (Franke)?

Conorbina spp.

Ellipsodimorphina spp.

Globulina lacrima Reuss

Lagena spp.

Marginulina spp.

Nodosarella gracillima Cushman?

Pseudoclavulina sp.

Pseudonodosaria manifesta (Reuss)

Pseudonodosaria mutabilis (Reuss)

Pullenia cretacea Cushman

Stensioina sp.

?lower Turonian

Dentalina catenula Reuss?

Dentalina communis d'Orbigny

Dentalina gracilis d'Orbigny

Dentalina spp.

Gyroidina spp.

Lenticulina circumcidanea (Berthelin)

Lenticulina excentrica (Cornuel)?

Lenticulina macrodisca (Reuss)?

Lenticulina scitula (Berthelin)?

Lenticulina sternalis (Berthelin)

Marginulina calliopsis Reuss?

Marginulina spp.

Nodosaria aspera Reuss

Pleurostomella subnodosa Reuss?
Table 1. (Continued.)

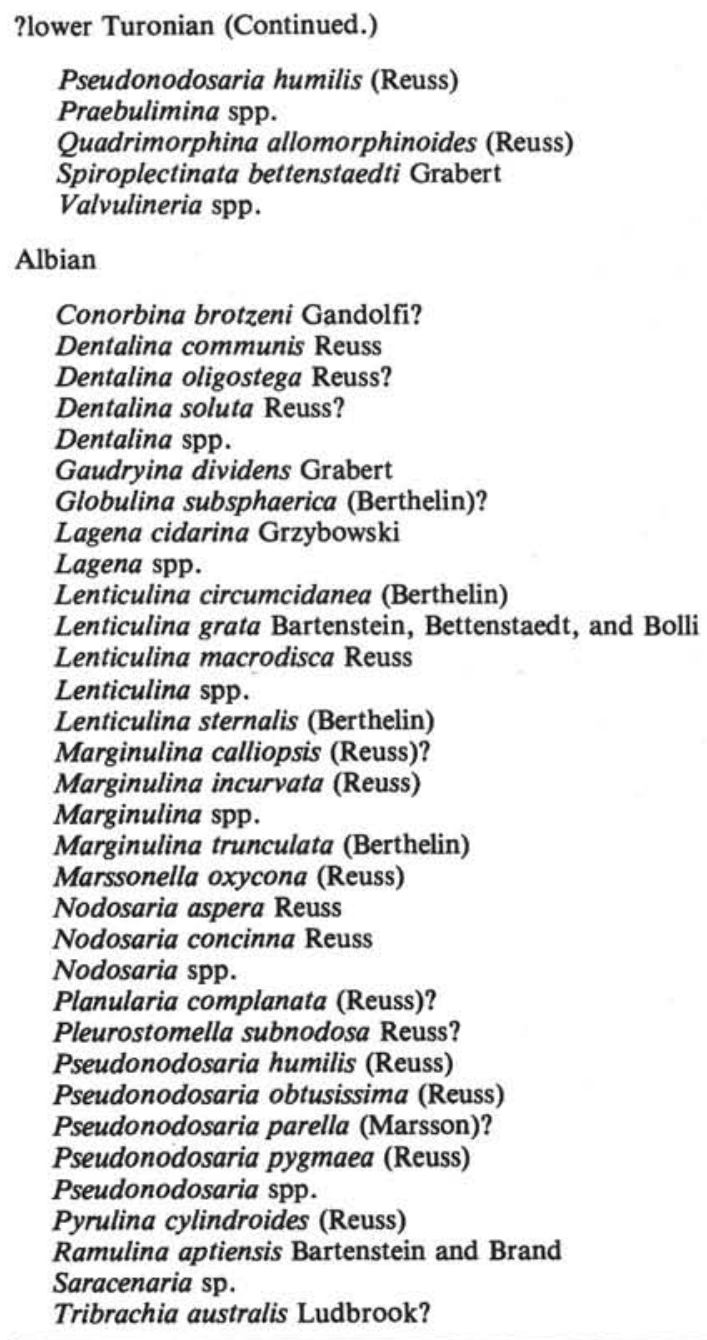

The lower part of this interval (Cores 87 through 92) is marked by the presence of black shales among the variegated clastics mentioned above. The lithofacies distinguishes Unit 8, which continues to the bottom of the sedimentary section of Hole 530A. Planktonic specimens are common in black shale samples from Core 88, Section 3, 120-122 cm and Core 92,CC but are absent or very rare in other lithofacies. Benthos of an agglutinated fauna were recovered from the red and green claystones, and other benthos are abundant in some residues from light gray turbiditic thin beds.

Whether rare or common, planktonic populations are dominated by Marginotruncana pseudolinneiana Pessagno and $M$. sinuosa Porthault. The form of the latter species (Robaszynski and Caron, 1979, pl. 74, figs. 2a-c) which is similar to Globotruncana fornicata Plummer (1931, pl. 13, figs. 5a-c) is relatively prominent. Dicarinella concavata (Brotzen) and related $D$. hagni (Scheibnerova), D. primitiva (Dalbiez), and $D$. $\mathrm{sp}$. are prominent in Core 88 , Section 3, 120-122 cm. Infrequent, rare, and poorly preserved specimens of $M$. coronata (Bolli), M. renzi (Gandolfi), and M. marginata (Reuss) are present. Hedbergella flandrini Porthault is 
Table 2. Distribution of recurrent planktonic species from Cores 75-105, Hole 530A, Leg 75 . $^{\mathrm{a}}$

\begin{tabular}{|c|c|c|c|c|c|c|c|c|c|c|c|c|c|c|c|c|c|c|c|c|c|c|c|c|c|c|c|c|c|c|c|}
\hline \multirow[b]{2}{*}{ Species } & \multicolumn{10}{|c|}{ Albian } & \multicolumn{3}{|c|}{ Turonian } & \multicolumn{18}{|c|}{ Coniacian-Santonian } \\
\hline & 105 & 104 & 103 & 102 & 101 & 100 & 99 & 98 & 97 & 96 & 95 & 94 & 93 & 92 & 91 & 90 & 89 & 88 & 87 & 86 & 85 & 84 & 83 & 82 & 81 & 80 & 79 & 78 & 77 & 76 & 75 \\
\hline $\begin{array}{l}\text { Hedbergella infracretacea } \\
\text { Hedbergella planispira } \\
\text { Hedbergella simplex } \\
\text { Hedbergella delrioensis } \\
\text { Dicarinella canaliculata? }\end{array}$ & & $\begin{array}{l}\mathrm{C} \\
\mathrm{R} \\
\mathrm{F}\end{array}$ & $\begin{array}{l}\mathrm{R} \\
?\end{array}$ & & & & & & & & $\begin{array}{l}\mathbf{F} \\
\mathbf{C}\end{array}$ & $\begin{array}{l}\mathbf{R} \\
? \\
\mathrm{~F} \\
\mathrm{R}\end{array}$ & & & & & & $\begin{array}{l}\text { C } \\
?\end{array}$ & & $\mathbf{R}$ & & & $\mathbf{R}$ & & & & & & & & \\
\hline $\begin{array}{l}\text { Dicarinella imbricata } \\
\text { Dicarinella concavata } \\
\text { Hedbergella flandrini } \\
\text { Marginotruncana coronata? } \\
\text { Marginotruncana marginata }\end{array}$ & & & & & & & & & & & $\mathbf{R}$ & C & & $\begin{array}{l}\mathbf{R} \\
? \\
\mathrm{R} \\
\mathrm{R} \\
?\end{array}$ & & & & $\begin{array}{l}\stackrel{?}{\mathrm{C}} \\
\mathrm{F} \\
\mathrm{F} \\
?\end{array}$ & $\begin{array}{l}? \\
\text { F }\end{array}$ & $\begin{array}{l}\mathbf{R} \\
\mathbf{R} \\
\mathbf{R}\end{array}$ & & $\mathbf{R}$ & $\mathbf{R}$ & & $\mathbf{R}$ & & & & & & \\
\hline $\begin{array}{l}\text { Marginotruncana pseudolinneiana } \\
\text { Marginotruncana sinuosa } \\
\text { Schackoina cenomana bicornis } \\
\text { Globotruncana fornicata } \\
\text { Dicarinella asymmetrica }\end{array}$ & & & & & & & & & & & $\begin{array}{l}\mathrm{C} \\
\mathrm{C}\end{array}$ & $\begin{array}{l}\mathrm{C} \\
\mathrm{C} \\
\mathrm{C}\end{array}$ & & $\begin{array}{l}\mathrm{C} \\
\mathrm{R}\end{array}$ & & $\begin{array}{l}\mathbf{R} \\
\mathbf{R}\end{array}$ & & $\begin{array}{l}\mathrm{A} \\
\mathrm{C}\end{array}$ & $\begin{array}{l}\mathbf{R} \\
\mathbf{R}\end{array}$ & $\begin{array}{l}\mathrm{C} \\
\mathrm{R} \\
\mathrm{R}\end{array}$ & & & & $\begin{array}{l}\mathbf{R} \\
\mathbf{R}\end{array}$ & & $\begin{array}{l}\mathbf{A} \\
\mathbf{R}\end{array}$ & $\stackrel{\mathrm{A}}{\mathrm{F}}$ & $\begin{array}{l}\mathbf{F} \\
\mathbf{R}\end{array}$ & A & & C \\
\hline $\begin{array}{l}\text { Globotruncana arca } \\
\text { Globotruncana elevata } \\
\text { Globotruncana linneiana } \\
\text { Globotruncana stuartiformis } \\
\text { Globotruncana ventricosa }\end{array}$ & & & & & & & & & & & & & & & & & & & & & & & & & & $\begin{array}{l}\text { A } \\
\text { C } \\
\text { R }\end{array}$ & $\begin{array}{l}\mathrm{C} \\
\mathrm{R} \\
\mathrm{C} \\
\mathrm{F} \\
\mathrm{R}\end{array}$ & $\begin{array}{l}\mathbf{F} \\
\mathbf{F} \\
\mathbf{R}\end{array}$ & $\begin{array}{l}\mathbf{R} \\
\mathrm{C}\end{array}$ & $\begin{array}{l}\mathbf{F} \\
\mathbf{R}\end{array}$ & $\begin{array}{l}\mathrm{C} \\
\mathrm{R}\end{array}$ \\
\hline Planoglobulina glabrata & & & & & & & & & & & & & & & & & & & & & & & & & & $\mathbf{R}$ & $\mathbf{F}$ & & $\mathbf{R}$ & & $?$ \\
\hline
\end{tabular}

a Planktonic occurrences above Core 75 are too infrequent to justify plotting

Table 3. Distribution of recurrent planktonic species from Cores 81-105, Coniacian-Santonian to Albian, Hole 530A, Leg 75.

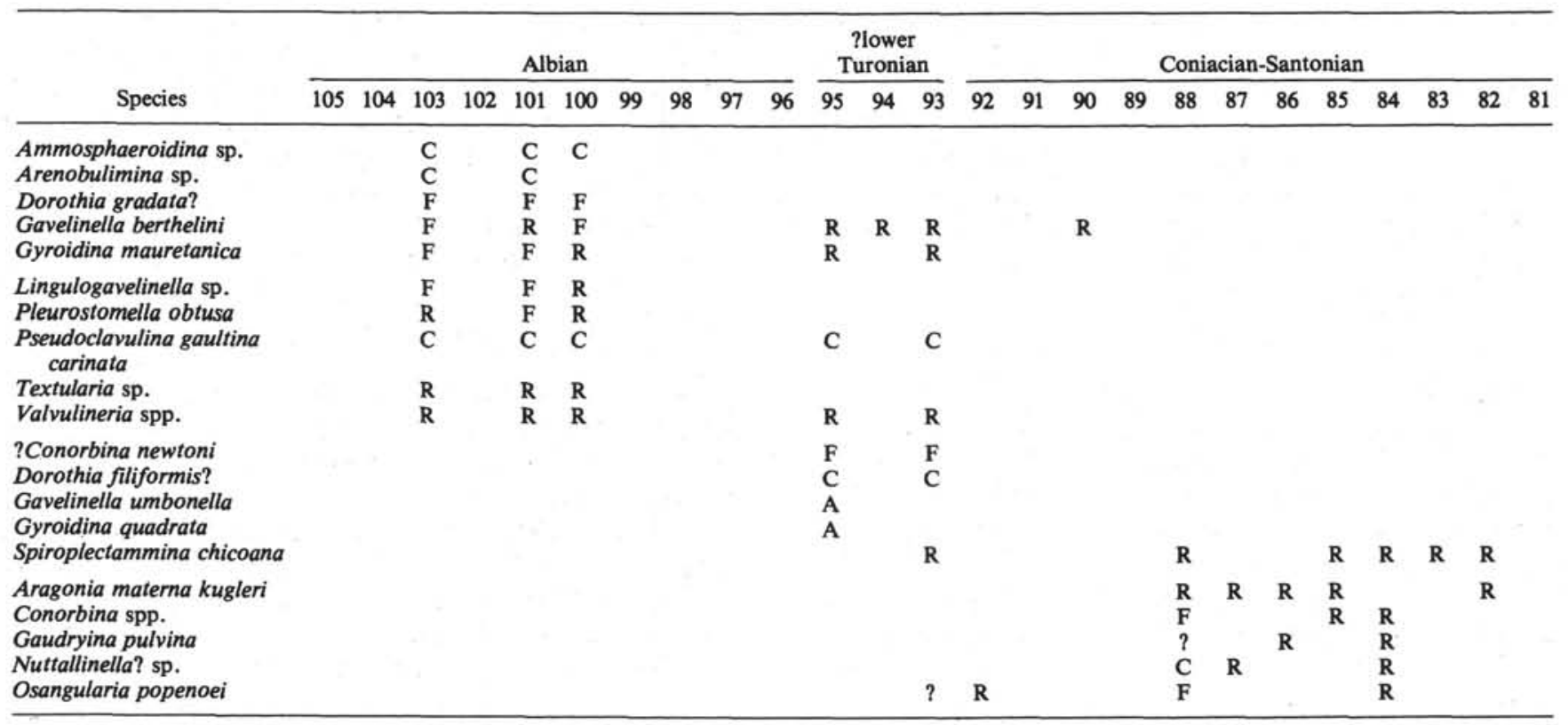

Table 4. Distribution of recurrent benthic species from the Campanian and Maestrichtian, Hole 530A.

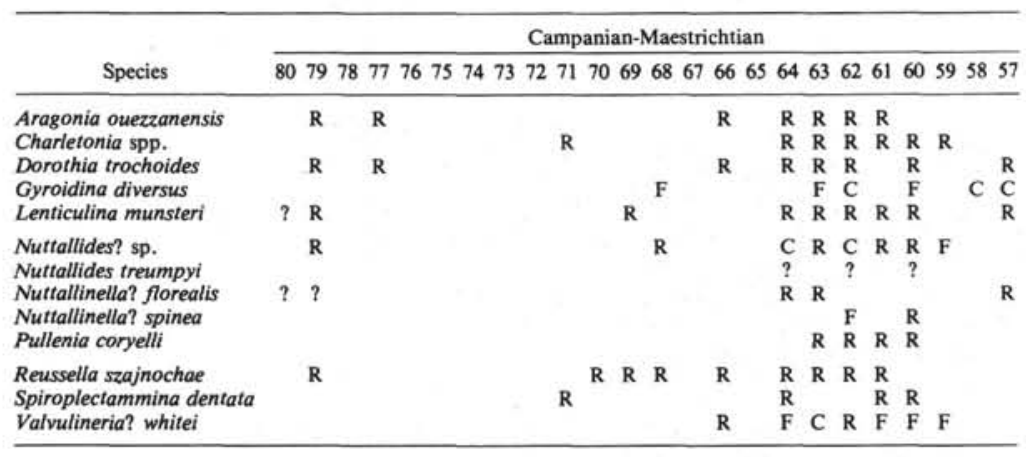


uncommon but persistent. Typically nodose to costellate globigeriniform specimens are common and may represent a variety of taxa, but the umbilical properties and apertural characters are poorly preserved; consequently, these are presented below as Hedbergella ssp.

The agglutinated benthic fauna of the red and green claystones includes Ammodiscus cretaceus (Reuss), Bathysiphon sp., Glomospira charoides (Parker and Jones), G. corona Cushman and Jarvis, Haplophragmoides coronata (Brady), G. multicarinata Krasheninnikov, Hormosina sp., Hyperammina sp., Labrospira inflata Krasheninnikov, Paratrochamminoides sp., Pelosina complanata Franke, Praecystammina globigerinaeformis altiformis Cushman and Renz, Reophax sp., Saccammina rhumbleri (Franke), Trochammina sp., and Uvigerinammina jankoi Majzon. It is likely that additional taxa are present, but they could not be separated.

Benthic species from other lithofacies are more advanced agglutinated or hyaline forms. Only the following species are persistent in the Santonian-Coniacian interval: Aragonia materna kugleri Beckmann and Koch, Gaudryina pulvina Belford, Conorboides sp., Nuttallinella? sp. (Globorotalites conicus of authors), Osangularia popenoei (Trujillo), and Spiroplectammina chicoana Lalicker. Infrequent and rare species are listed elsewhere.

The Santonian-Coniacian assignment is indicated by the marginotruncanids, particularly the Dicarinella concavata, by the sparse but persistent Hedbergella flandrini, and by three of the rare but persistent benthics, namely Aragonia materna kugleri, Osangularia popen$o e i$, and Spiroplectammina chicoana.

\section{?LOWER TURONIAN}

The faunules of this interval, Cores 93 through 95, are marked by a mixing of upper and lower Cretaceous elements. Most of the plankton and some of the benthos are lower Turonian or younger, whereas most of the benthos and a few plankton are typical of, if not limited to, the Albian. In any case, the interval of only $30 \mathrm{~m}$ represents a long lacuna for most of the Turonian, the Cenomanian, and possibly some of the Albian.

The simple agglutinated species of the red and green claystones are not as frequent in residues from this interval as in the Santonian-Coniacian, possibly because my sampling concentrated on the turbidites and black shales.

Distorted bicarinate globotruncaniform and spinose, nodose, to partially costellate hedbergelliform planktonic species are common to abundant in some black shales but are rare to absent in the red and green claystones. Dicarinella canaliculata (Reuss)?, D. imbricata (Mornod), Marginotruncana pseudolinneiana Pessagno, and $M$. coronata (Bolli)? are prominent representatives of the globotruncaniforms. Hedbergella delrioensis (Carsey), H. hoezli (Scheibnerova)?, H. planispira (Tappan), and $H$. simplex (Morrow) are typical hedbergellids. Most of the hedbergelliform specimens are poorly preserved, and additional species may be present, as well as representatives of other genera, such as Whiteinella, but they could not be identified with confidence and are not reported here. Schackoina cenomana (Schacko), includ- ing $S$. cenomana bicornis Reichel, is prominent in Cores 94 and 95.

The prominent or persistent benthic species include Dorothia filiformis (Berthelin)?, Gavelinella berthelini Keller?, Gavelinella umbonella (Reuss), Gyroidina quadrata (Cushman and Church), ?Conorbina newtoni Eicher and Worstell, Pseudoclavulina gaultina carinata Neagu, and Spiroplectammina chicoana Lalicker.

The apparent temporal contradictions among faunal elements of this interval could have resulted from redrilling cavings, reworking, a very incomplete section, or some combination of these, and there is evidence for all of them. Some of the prominent, typically older species, such as Gavelinella berthelini, Pseudogaudryina gaultina carinata, and Schackoina cenomana bicornis, have been reported from younger rocks (Keller, 1935; Neagu, 1962; Porthault, 1974), and it is barely possible to accommodate these and the planktonic species of the interval within the lower Turonian; hence that assignment is employed here with question.

\section{ALBIAN}

The most persistent and frequent microfossils of this interval (Cores 96 through 105) are silica-filled radiolarian tests. They are most common in the greenish gray siltstones but occur in other lithofacies of the interval, including the black claystones. Where radiolarians are common, foraminifers are typically rare or absent. Inoceramid prisms are common to abundant in three of the eight fossiliferous samples.

A sparse, narrow fauna of primitive agglutinated foraminifers occurs in the red and green claystones of the interval. Most specimens are badly deformed, limiting identifications to Ammodiscus cretaceus (Reuss), Bathysiphon sp., Glomospira charoides (Jones and Parker), Haplophragmoides sp., Hyperammina sp., ?Labrospira sp., Lituotuba sp., Plectorecurvoides sp., Proteonina sp., and Rhabdammina sp.

The most conspicuous taxa are relatively large and frequent, smoothly finished agglutinated forms, namely Ammosphaeroidina sp., Arenobulimina sp., Dorothia gradata (Berthelin)?, and Pseudoclavulina gaultina carinata Neagu. Also persistent are Gavelinella berthelini (Keller) (G. intermedia group), Gyroidina? mauretanica Charbonnier, Lingulogavelinella sp. (L. albiensis group), Pleurostomella obtusa Berthelin, and $P$. reussi Berthelin. At least two dozen species of typical lower Cretaceous nodosariids and polymorphinids are represented by one to three broken specimens in one or two occurrences, but they are evidently displaced forms and are not listed here.

Planktonic specimens are absent to rare in all but one sample $(104-2,49-52 \mathrm{~cm})$, in which about $25 \%$ of the population is composed of size-graded small hedbergellids, including Hedbergella infracretacea (Glaessner), $H$. libyca Barr, H. planispira (Tappan), and H. simplex (Morrow).

\section{DISPLACED FAUNAS}

As mentioned in the introduction, most of the benthic species encountered are represented by rare specimens from one or two samples. They are typically 
broken, worn, and etched. Species represented by such specimens were interpreted to have been transported from shallower sites in which they had lived as contemporaries of the indigenous species of Site 530. These displaced species are not to be confused with reworked species from exhumed older sediments and redeposited, nor with redrilled species derived from uphole cavings.

The displaced species are presented in groups (Table 1) that correspond with the chronostratigraphic intervals, such as Maestrichtian-Campanian. Some of the species occur in more than one group, but most of them occur in one group only, indicating that displaced species can have some temporal significance.

On the other hand, the displaced species of a group show considerable variation in paleoecologic implications. Comparison of the Maestrichtian-Campanian displaced faunal list (Table 1) with generic works, such as Cushman, 1946, and van Morkhoven, 1981, shows that the fauna varies at least from neritic to bathyal, and I would say from middle neritic to middle bathyal. Moreover, the rarity of planktonic species in these samples and the broken, worn, and dissolutive condition of the benthic tests combine to require greater paleodepths than the taxonomic composition of the fauna implies. In short, it appears that displaced faunas are not reliable paleodepth indicators.

\section{DEPOSITIONAL ENVIRONMENT}

The principal aspects of these foraminiferal populations are sparsity of specimens in the residues, rarity of planktonic specimens, low taxonomic diversity, and prevalence of etched, worn, and broken specimens.

Most of the 148 Cretaceous samples from Hole 530A did not yield foraminifers, and most of those that did so yielded only small numbers of specimens from the $10 \mathrm{~cm}^{3}$ samples. Such low frequency can occur in several foraminiferal habitats, but it is particularly characteristic of the very deep environments.

The relatively few fossiliferous residues were dominated by benthic forms, except for three short intervals centering around Cores 79,88 , and 94 . There can be no question that Site 530 was well below the planktonic lysocline during most of the Maestrichtian-Albian and was close to that position during the short intervals of relatively abundant plankton. The position of the lysocline and the CCD vary with time in response to changes in oceanic chemistry; consequently, it might be argued that the planktonic rarity in Hole 530A is the result of an elevated lysocline. However, it could not have been elevated much, because the plankton are common in coeval rocks at nearby paleobathyal Sites 363 (see other interpretation, Scheibnerová, 1978) and 364 of Leg 40. Generally the planktonic lysocline is associated with the base of the lower bathyal or deeper realms.

The three short intervals of relative planktonic abundance approximately at Cores 79,88 , and 94 might be interpreted as evidence of shallower seafloors, but there are reasons for doubt. First, the sediment is turbiditic, not truly pelagic. Second, the specimens, both planktonic and benthic, are etched, worn, and broken. Addi- tional comments are presented in the Depositional Record below.

The total number of benthic species for an interval of Hole 530A, such as the Maestrichtian-Campanian, is too large for deep realms, such as lower bathyal or abyssal, but recognition of displaced faunas clarifies what the indigenous benthic faunas are, and their taxonomic diversity is very low for all of the Cretaceous encountered in Hole 530A. Like sparsity of numbers, low benthic taxonomic diversity alone is not proof of the deeper realms, but it is pronounced in them.

Most of the species of the indigenous benthic faunas of Hole 530A are well known. They have been reported from samples with abundant plankton or with other evidence of bathyal habitat (e.g., Gandolfi, 1942; van Morkhoven, 1981). However, their occurrence in Hole $530 \mathrm{~A}$ is marked by the absence of accompanying abundant planktonic species, and that indicates that these indigenous benthic species lived below the planktonic lysocline as well as above it.

The dominance of etched, worn, and broken specimens occurs throughout the Cretaceous of Hole 530A. Its prevalence, even among the indigenous benthos, extends the paleobathymetric implications of the rare plankton to paleodepths very near to the CCD.

The primitive, quartzose, agglutinated faunas of the red and green claystones are strongly suggestive of a paleodepth below the CCD, for they include no calcitic species, not even calcareous agglutinated forms. This kind of fauna has been interpreted as abyssal by Krasheninnikov $(1973,1974)$ and Beckmann (1978), and as deep abyssal by Sliter (1977a, b). Red and green claystones were first encountered in the basal part of the Maestrichtian-Campanian interval (lithologic Unit 7, Core 75 ) and continued with increasing prominence to the base of the sedimentary succession. For this lower part of Hole 530A, varicolored claystone is the basic sediment, into which various turbidites were introduced, and upon which the black claystones were superimposed.

The combination of faunal characteristics listed above implies a depositional site well below the planktonic lysocline, below the benthic lysocline, and close to, if not below, the CCD. Such a location should be in the abyssal realm, which is taken here to mean $2500 \mathrm{~m}$ or more (see Sliter, 1977b, p. 667). The very similar upper Cretaceous fauna of Site 355 in the Brazil Basin has been reported as paleoabyssal at a paleodepth of $3000-4000 \mathrm{~m}$ (Sliter, 1977b, p. 657, 667). This conforms to the paleodepths proposed elsewhere in this volume.

The relative abundance and number of species of the displaced faunas increase from the base to the top of Cretaceous in Hole 530A. This is interpreted to be a result of increasing proximity to a prograding continental margin.

There is no evidence for the nature of the transporting mechanisms within the species or specific associations of the foraminifers, but the sedimentological properties of the cores are interpreted (Stow, this volume) as those of a submarine fan system, which appears to be an 
ideal mechanism for production of characteristics of these faunas.

\section{FAUNAL SIMILARITIES}

The Cretaceous faunas of Hole 530A conform most closely to those of the Brazil and Argentine basins (Sliter, 1977b), are similar to the abyssal South Atlantic sites (Sliter, 1977a, p. 530, fig. 10), and are a part of the Austral Biogeoprovince of the South Atlantic and Indian Oceans (Scheibnerova, 1973, 1974, 1978; Sliter, 1977a, b; Premoli Silva and Boersma, 1977; Beckmann, 1978).

Justification for the first assertion above is based primarily on similarity of faunas (see Sliter, 1977b, Sites 355 and 356), but it is also supported by differences between Site 530 and nearby paleobathyal Sites 363 and 364 of Leg 40 (Beckmann, 1978; Caron, 1978; Scheibnerová, 1978). The faunas of the Leg 40 sites include more plankton, more diverse plankton, and more diverse benthos. Thus Cretaceous faunas of Site 530 are more like other paleoabyssal sites of the southern hemisphere than nearby sites of different paleobathymetry.

The evidence for relationship to the Austral Biogeoprovince seems to vary with paleodepth of the species concerned. Even the few planktonic specimens of Hole 530A show clear relationship to the well-differentiated midlatitudinal assemblages of the southern hemisphere (Sliter, 1977a, especially p. 534; 1977; Premoli Silva and Boersma, 1977). The upper Cretaceous displaced benthic faunas of Hole 530A are quite like those of coeval nearby paleobathyal Sites 363 and 364, and both are distinguishable from coeval Boreal faunas on the specific level, although it is surprising how many species of the Austral fauna occur in Boreal faunas also. The paleoabyssal Albian of Hole 530A is, however, cosmopolitan, as is illustrated by the distribution of Pseudoclavulina gaultina (also reported as Clavulina gabonica, Tritaxia gabonica, etc.), which has a wide geographic and paleolatitudinal range. Taken at face value, the Albian benthic fauna from Hole 530A indicates widespread homogeneity of abyssal water, quite different circulation from shallow water, and absence of dominant and strongly contrasting South Atlantic polar water in the Angola Basin.

\section{DEPOSITIONAL RECORD}

The most conspicuous property of the Cretaceous sequence is the brevity of the medial Cretaceous record, which is represented by Cores 93 through 95 . There is evidence of redrilled cavings, reworked Albian specimens, and an erratically sequential succession. It is impossible to be certain which species are indigenous and risky to employ the principle of age-dating by the youngest species present. The sequence could be of any age or of any sequence of ages between the Turonian and somewhere in the late Albian.

Regardless of the interpretation, there is a long middle Cretaceous lacuna, or succession of lacunae, in the depositional record of Hole 530A. The same is true and characteristic of other DSDP sites in the southern hemisphere, as has been amply demonstrated (Sliter, 1977a, b; Premoli Silva and Boersma, 1977; Beckmann, 1978; Scheibnerová, 1978). There appears to be no property in the faunas of Hole 530A that would contribute to an explanation for this phenomenon, unless it is the change from cosmopolitan, abyssal faunas of the Albian to latitudinally differentiated abyssal faunas of the Coniacian and younger rocks, suggesting the arrival of colder South Atlantic abyssal water in the Angola Basin.

The brief expansions of the planktonic fauna at the horizons of Cores 88 and 79 are not related to significant shallowing but may reflect reduced sedimentation. The expansion around Core 88 is close to the top of the mid-Cretaceous unconformity, and that around Core 79 is associated with relatively abundant glauconite. However, it seems unlikely that the typical physical properties of an unconformity would occur in the depositional environment of a submarine fan.

It was difficult to determine the exact relationship of foraminiferal samples to black shales. It appeared, however, that my samples came from laminae and thin beds of biogenic calcitic siltstone and silty claystone within the black shales. Samples from the well-developed black claystones of Core 98 yielded no foraminifers, yet radiolarians were present. Foraminifers from black claystones of Core 88 are relatively abundant and, by the standards of Hole 530A, well preserved, but the samples came from lighter colored thin beds as has been mentioned. Planktonic foraminifers from the black claystones are less dissolutive than those from other lithofacies, indicating that the environment producing the black claystones favored the preservation of foraminiferal tests. This does not mean that the environment was favorable to living foraminifers.

\section{CONCLUSIONS}

Most of the Cretaceous benthic species encountered in Hole 530A are displaced species, represented by specimens transported downslope from their natural habitat. They are not to be confused with reworked species. Displaced faunas have temporal value but do not have paleobathymetric value. Displaced species were recognized by their rarity, infrequency of occurrence, and physical state of dissolution, abrasion, and fragmentation.

Cretaceous foraminiferal populations from Hole 530A are characterized by sparsity of specimens, rarity of planktonic species, low diversity of indigenous benthic species, and prevalent dissolution, abrasion, and fragmentation of specimens. These properties, the primitive, quartzose, agglutinated faunas of abyssal red and green claystones, and the displaced faunas combine to show that the depositional environment at Site 530 was well below the planktonic lysocline, below the benthic lysocline, and close to, if not below, the CCD, and consequently in the abyssal realm in excess of $2500 \mathrm{~m}$. The sum of these properties and the persistence and relative abundance of the displaced, calcitic, benthic faunas suggest deposition on the deep seafloor by an established transport system with access to all paleodepths; hence, perhaps a submarine fan. The relative abundance and diversity of the displaced faunas increase from the $\mathrm{Al}$ - 
bian into the Maestrichtian, suggesting increasing proximity to a prograding continental margin.

The Cretaceous faunas of Hole 530A are most similar taxonomically to those of the paleoabyssal sites of Leg 39 in the Argentine and Brazil basins of the western South Atlantic. They are more like distant paleoabyssal sites of the southern hemisphere than like nearby paleobathyal and shallower sites of Leg 40 on the African continental margin.

The planktonic faunas of Hole 530A belong to the middle latitudinal, Austral Biogeoprovince. The displaced faunas are much like the paleobathymetrically shallower nearby sites of Leg 40, which are more definitely Austral. Upper Cretaceous indigenous benthos are also Austral, but the diversity is low and most species also occur in Boreal realms. In contrast, the $\mathrm{Al}$ bian benthos of Hole 530A is cosmopolitan, including some species with wide geographic and latitudinal range. The contrast between cosmopolitan Albian and latitudinally differentiated upper Cretaceous benthic faunas of Hole 530A could reflect the absence and presence of colder South Atlantic water.

The principal event of the Cretaceous record at Site 530 is the medial Cretaceous lacuna, which includes much, if not all, of the Turonian, the Cenomanian, and part of the Albian. This lacuna is widespread in the southern hemisphere. Nothing in the foraminifers of Hole $530 \mathrm{~A}$ contributes to an explanation of this phenomenon, with the possible exception of the Albian and upper Cretaceous contrast in indigenous abyssal benthic faunas mentioned above.

There is some indication of hiatuses nearby and related to the brief relative abundances of planktonic specimens around Core 94 (?lower Turonian), Core 88 (Coniacian), and Core 79 (lower Campanian).

There is some evidence that foraminifers from the black claystones actually came from thin beds of turbiditic, biogenic arenites, and silty claystones. Where the arenites and arenitic claystones are intimately mixed with black claystones, the foraminifers are less dissolute than elsewhere, suggesting that the environment of the black claystones was favorable to the preservation of calcitic tests.

\section{SELECTED SYSTEMATIC PALEONTOLOGY}

Most of the persistent benthic species are considered here. Because of their poor preservation and architectural simplicity, only a few of the scores of SEM photomicrographs proved informative. Consequently, outline drawings have been made for the majority of species involved.

In this section and elsewhere, genera such as Clavulinoides, Marssonella, and Pseudoclavulina are used with knowledge of current practice otherwise.

\section{Ammosphaeroidina sp.}

(Plate 1, Figs. 11-14; Plate 3, Figs. 9-11)

Ammosphaeroidina sp. Gandolfi, 1942, p. 49, fig. 10.

?Gubkinella graysonensis (Tappan) Luterbacher, 1975, pl. 2, figs. 4-8 (p. 713).

Sphaeroidina sp. McNulty, 1976, p. 373 (in faunal list of Core 7-9 interval).

The coiling and increase in chamber size vary. Some specimens have a more conic initial portion, more gradual increase in size of final chambers, and a resemblance to Gubkinella. Typically, the initial por- tion is reduced and the increase in chamber size is abrupt and large but stable in the final whorl, resulting in the sphaeroidine form. The shape of the aperture could not be established; it seemed to be a low, elongate, interiomarginal opening, but may be triangular, and possibly with an overhanging lip. The wall structure is also uncertain in that the interlocking texture exhibited may not be primary. Some specimens from Leg 33 are somewhat streptospiral, like the genotypic species.

The species has been reported from the Aptian, Cenomanian, and Albian of the Breggia section, Italy (Gandolfi, 1942), the Albian of the Shatsky Rise in the northwest Pacific (Luterbacher, 1975), and the Albian of the Manihiki Plateau in the southwest Pacific (McNulty, 1976). It appears to have been a bathyal to abyssal form. It is relatively common, persistent, and a conspicuous element of the Albian fauna of Hole 530A.

\section{Aragonia materna kugleri Beckmann and Koch}

(Plate 2, Fig. 2)

Aragonia materna kugleri Beckmann and Koch, 1964, p. 4, pl. 7, figs. 14-17.

?Aragonia ouezzanensis (Rey) Hanzlikova, 1972, p. 121, pl. 35, fig. 13a, b, not 14 .

The specimens assigned to this species resemble $A$. ouezzanensis but are thinner and have lower flanges on the intercameral sutures and a more gradually broadening initial one-half of the test. val.

The species is rare but persistent in the Santonian-Coniacian inter-

\section{Aragonia ouezzanensis (Rey)}

(Plate 2, Fig. 3)

Bolivinoides ouezzanensis Rey, 1954 p. 209, pl. 12, fig. 2.

Aragonia ouezzanensis (Rey) Sliter, 1977b, p. 687, pl. 7, figs. 9-10; Beckmann, 1978, p. 764, pl. 3, fig. 25; Proto Decima and Bolli, 1978, p. 790, pl. 3, fig. 22.

Aragonia trinitatensis (Cushman and Jarvis) Hanzliková, 1972, p.

122, pl. 35, figs. 9a, b, 10; Douglas, 1973, p. 628, pl. 4, figs. 7-9.

The variation within species of Aragonia has not been established, and concepts of the species are varied. Aragonia ouezzanensis of this report is characterized by chambers that extend far back toward the proloculus and produce a very obtuse outline of the initial part of the test, rapid thickening along the posterior-anterior line, and sharp, partially carinate lateral margins. Secondary flanges extending from the sutural flanges onto the chamber faces are absent or few and poorly developed.

Aragonia ouezzanensis is typically rare, but it is the most persistent species in the Maestrichtian-Campanian interval.

\section{Arenobulimina sp.}

(Plate 1, Fig. 9; Plate 3, Figs. 5-8)

Test agglutinated, calcitic, smoothly finished, variably trochospiral, with three or four chambers in each of about four whorls, of which the last one composes most of the test; axis of coiling bent and chambers enlarged abruptly at junction of the small initial portion and the large final portion of test; chambers spheroidal but appressed; sutures flush and obscure; aperture varying from arched, interiomarginal to rounded, areal, subterminal, as coiling of final whorl varies from tight to loose.

Most specimens are very short and globose like Arenobulimina brevicona (Perner), but many are somewhat elongate like $A$. chapmani Cushman; some of them have loose coiling, a suggestion of uniseriality, and a subterminal aperture, which typifies $A$. anglica Cushman. Rare specimens are definitely elongate, aperturally terminal, and close to loose biseriality in the final chambers.

Few to common, persistent, and conspicuous in the Albian.

Charletonia spp.

(Plate 4, Figs. 29-34)

The specimens of this assignment vary from inflated biconvex to roundly plano-convex, from six to eight chambers per whorl, and from completely involute umbilically to slightly evolute with a small calcite-filled umbilicus. The intercameral umbilical sutures are typically sinuous, although also evenly curved; the intercameral spiral sutures are strongly oblique and slightly curved to straight. The low in- 
teriomarginal aperture bends posteriorly in proximity to and in the plane of the carinate periphery. As these properties vary, the individual specimens resemble different species, such as Pulvinulinella ripleyensis Sandidge, 1932, Eponides menterelensis Marie, 1941, Pseudoparella meeterenae Visser, 1950, P. minisae Visser, 1951, and Pulvinulinella cretacea Sacal and Debourle, 1957. Specimens from Hole 530A are small, typically rare, and poorly preserved, making distinctions among them untenable. However, such forms are persistent in the Maestrichtian-Campanian interval and are cited here.

\section{?Conorbina newtoni (Eicher and Worstell)}

(Plate 2, Figs. 4, 5; Plate 3, Figs. 18-20)

Lingulogavelinella newtoni Eicher and Worstell, 1960, p. 294, pl. 5, figs. 2-4.

The specimens appear identical to $L$. newtoni in most respects, but the apertural and umbilical details could not be established.

The species is few to common and persistent in the ?lower Turonian interval.

\section{Dorothia filiformis (Berthelin)?}

(Plate 1, Fig. 7)

Gaudryina filiformis Berthelin, 1880, p. 25, pl. 1, fig. 8a-d.

The specimens are crushed, and the identification is questionable. Rare in the ?lower Turonian interval.

\section{Dorothia gradata (Berthelin)?}

(Plate 1, Fig. 10)

Gaudryina gradata Berthelin, 1880, p. 24, pl. 1, fig. 6a-c.

The specimens differ from $D$. gradata in broadening more rapidly, in having relatively low and broad chambers in the biserial part of the test, and in many tests having a distinctly larger final pair of chambers. The form is close to Dorothia conula (Reuss). However, Bartenstein and Bolli (1973, pp. 397-398) report similar properties for $D$. gradata from Trinidad. The rapidly broadening $D$. gradata from the Manihiki Plateau of the southwestern Pacific (McNulty, 1976) has no quartz silt in the walls, higher chambers in the biserial portion, and more deeply depressed sutures.

Uncommon but persistent in the Albian of Hole 530A.

\section{Dorothia trochoides (Marsson)}

Gaudryina crassa var. trochoides Marsson, 1878, p. 150, pl. 3, fig. $27 \mathrm{~d}-\mathrm{f}$.

Dorothia trochoides (Marsson) Beckmann, 1978, p. 765, pl. 1, fig. 22. Although this species was defined as a variant of one with an established biserial terminal stage and is indistinguishable from the juvenile stage of several Dorothia (Plummer, 1931, pl. 8, figs. 15-17), it has continued to be reported as a taxonomic entity. It is one of the more persistent taxa of the Maestrichtian-Campanian interval of Hole 530A, whereas specimens of Dorothia occur at only a few horizons within the interval.

\section{Gaudryina pulvina Belford}

(Plate 3, Figs. 3, 4)

Gaudryina pulvina Belford, 1960, pp. 10, 11, pl. 2, figs. 1-7.

Gaudryina rugosa d'Orbigny Belford?, 1960, p. 13, pl. 2, figs. 17-19, not fig. 16.

Specimens from Hole 530A have a short biserial stage, and most show some degree of blunt carination of the lateral margin of one of the biserial edges. The latter character appears in one of Belford's specimens (see above) assigned to Gaudryina rugosa, which lacks the character. The ridged appearance of the biserial chambers is shown by all specimens from the Santonian-Coniacian interval, wherein $G$. pulvina is a rare but persistent species.

\section{Gavelinella berthelini (Keller)}

(Plate 2, Figs. 16, 17; Plate 4, Figs. 20-22)

Anomalina berthelini Keller, 1935, pp. 552, 558, pl. 3, figs. 25-27. Anomalina berthelini ten Dam, 1947, p. 105 (nomen nudum); ten Dam, 1950 , pp. 56, 57, pl. 4, fig. 9a-c.

Both Keller and ten Dam considered their species synonyms of Anomalina complanata Berthelin, not Reuss (Berthelin, 1880, p. 66 , pl. 4, figs. 12a-c, 13). As Moullade has noted (1966, p. 76$)$, the homonymy and apparent synonymy do not establish conspecificity of the holotypes, but all do appear the same, even though Keller's form was reported from the Cenomanian and all other reports known to me are from the Albian.

Uncommon but persistent in the ?lower Turonian and the Albian.

Gavelinella umbonella (Reuss)

(Plate 2, Fig. 13; Plate 4, Figs. 26-28)

Rotalia umbonella Reuss, 1860, p. 221, pl. 11, fig. 5a-c.

Although the specimens are very similar to Reuss's form from the Albian of Germany, it has not been reported since Reuss, 1863, and these specimens are very much like Rotalipora praebalernaensis evoluta Sigal (1969, p. 637, pl. 1, figs. 10-12), except for their apparent lack of secondary apertures and a definitely praebalernaensis-like primary aperture. However, these structures may be present and not demonstrable because of poor preservation of my material. This species also resembles Discorbis sp. (see Scheibnerová, 1978), a widely reported Austral species of the Albian.

The species is abundant in one sample from Core 95 , Section 2. $1-10 \mathrm{~cm}$ but is rare and infrequent elsewhere in the ?lower Turonian interval.

\section{Gyroidina diversus (Belford)}

(Plate 4, Figs. 8-10)

Eponides diversus Belford, 1960, p. 82, pl. 22, figs. 16-18.

As Belford indicated $(1960$, p. 82$)$, the variation within this species is exceptional, making the identification of poorly preserved and isolated specimens difficult. The shape varies from inflated plano-convex to uncommonly spiro-convex and the spiral, intercameral sutures from obtuse to almost tangential. The umbilical apex varies from a translucent calcitic filling, to closed, to a small open umbilicus beneath the umbilical margin of the final chambers. The most reliable property is the sinuous path of the umbilical, intercameral sutures, but even this may fail.

A comparison of $G$. diversus with Eponides bandyi Trujillo and $E$. goudkoffi Trujillo shows that all these may be synonymous. Belford's paper was issued 31 March, 1960, and Trujillo's paper was issued 15 April, 1960; thus Belford's nomen would have priority.

This is one of the most persistent and common benthic species of the Maestrichtian-Campanian part of Hole 530A.

\section{Gyroidina? mauretanica charbonnier}

(Plate 4, Figs. 11-13)

Gyroidina mauretanica charbonnier, 1952, p. 113, pl. 5, fig. 5a-c.

The generic assignment is questioned because of a posteriorly convex bend in the medial to lower portion of the apertural face. The sinuosity of sutures to which Charbonnier referred is a result of the bend, although prominence of the bend and of the sinuosity do not always conform. The pitch of coiling also varies, and the shape consequently varies from roundly plano-convex to spheroidal. The latter shape is typical of G. globosa as we know it from Reuss (1862, pl. 7, figs. $2 \mathrm{a}, \mathrm{b}$ ), but that nomen has become almost useless because of widespread and varied application.

Rare in ?lower Turonian; common and persistent in Albian.

Gyroidina quadrata Cushman and Church

(Plate 2, Figs. 10-12; Plate 4, Figs. 14-16)

Gyroidina quadrata Cushman and Church, 1929, p. 516, pl. 41, figs. 7-9.

This very distinctive species has been reported from the Coniacian (Beckmann, 1978) to the Maestrichtian (Sliter, 1968). The variety with peripheral spines (Gyroidinoides quadratus martini Sliter, 1968, p. 121; G. quadratus Sliter, 1977b, pl. 11, figs. 4-5, 7) was not seen.

Several specimens were found in Core 95, Section, $3,135-136 \mathrm{~cm}$ in the ?lower Turonian interval.

\section{Lenticulina velascoensis White}

(Plate 3, Figs. 12, 13)

Lenticulina velascoensis White, 1928 , p. 199 , pl. 28 , fig. 8 .

Lenticulina velascoensis White is distinguished by a relatively large number (about 12) of very gradually enlarging chambers arranged in carinate evolute coils that are visible through the large translucent um- 
bilical fillings, which merge smoothly with the flanks of the coils. White emphasized the low relief of the umbilical fillings and the compressed umbilical profile in peripheral view, but the specimens from Hole 530A show considerable variation in the topography of the umbilical fillings and suggest that his definition be modified to include forms of more varied umbilical topography.

Lenticulina velascoensis is similar to some specimens of $L$. munsteri (Roemer) as interpreted by Cushman (1946, pl. 17, fig. 5), but the latter has less evolution of coiling, more rapid increase in chamber height, narrower and thicker keel, or some combination of these properties.

Specimens are typically small and rare, but the species is one of the most persistent in the Maestrichtian-Campanian interval of Hole $530 \mathrm{~A}$.

\section{Lingulogavelinella sp.}

(Plate 2, Figs. 14, 15; Plate 4, Figs. 23-25)

The properties of the ventral side (terminology of Malapris, 1965) vary. Generally speaking, the languettes are large, thick, and separated by radial grooves of variable depth along most or all of the final whorl. However, some specimens have a central callus, which may or may not bear a spiral groove. These specimens are similar to Gavelinella intermedia (Berthelin). Other specimens have larger languettes that cover the ventral apex and extended meandering grooves between them, suggesting considerable evolution of final coiling on the venter. The last condition is proximal to Gavelinella (Lingulogavelinella) albiensis Malapris, as is the small calcite-filled apical region of the persistently more convex dorsal side. Similar specimens with fewer chambers have been defined from Leg 27 as Orithistella indica (Scheibnerová, 1974, p. 715 , pl. 7, figs. 4, 8-13; pl. 8, figs. 1-9; pl. 11, fig. $9 \mathrm{a}-\mathrm{c})$.

The species is rare to uncommon but is persistent in the Albian.

\section{Marssonella oxycona (Reuss)}

Gaudryina oxycona Reuss, 1860, p. 229, pl. 12, fig. 3a, b.

Suppression of Marssonella as a junior synonym of Dorothia (Trujillo, 1960, p. 309; Loeblich and Tappan, 1964, p. 275) is sound on the basis of morphologic relations, but the typical shape of Marssonella, its stability, and the range of the genus indicate that Marssonella is a distinct lineage and a valid genus. Hence it is used here.

Although it seems unlikely that all the reports of $M$. oxycona include one species, its occurrence in Hole $530 \mathrm{~A}$ is rare and infrequent, and the species could not be divided into more than the usual one.

Nuttallides? sp.

(Plate 3, Figs. 29-31)

?Eponides bronnimanni Cushman and Renz, 1946, p. 45, pl. 7, fig. $24 a-c$.

?Eponides florealis (White) Sacal and Debourle, 1957, p. 38, pl. 13, fig. 50.

Nuttallides bronnimanni (Cushman and Renz) Beckmann, 1978, p. 768 , pl. 3, figs. 1, 2.

This species is very similar to Nuttallides treumpyi (Nuttall), from which it differs mainly in having a more protruding, yet flattened, and typically wider umbonal plug. This species seems to be the same as the forms reported by Beckmann (1978), but none of my specimens definitely showed the intracameral structure of Nuttallides. The width of the plug and the sinuosity of the umbilical intercameral sutures vary; consequently, specimens close to Eponides bronnimanni Cushman and Renz ( $=E$. florealis Sacal and Debourle, 1957) occur, but the preservation of this small species is poor without exception and assignment to that species is questionable.

Nuttallides sp. is persistent and is often common in the Maestrichtian-Campanian interval.

\section{Nuttallides treumpyi (Nuttall)}

(Plate 3, Figs. 32-34)

Eponides treumpyi Nuttall, 1930, p. 287, pl. 24, figs. 9, 13, 14.

Very small, rare specimens occur at a few horizons within the Maestrichtian-Campanian interval.

\section{Nuttallinella? florealis (Cushman)}

Gyroidina florealis White, 1928, p. 293, pl. 40, fig. 3a-c.
The few and infrequent specimens are poorly preserved but seem to differ from Nuttallinella? spinea (Cushman) only in the lack of spines along the peripheral flange and of a secondary deposit of granular calcite on the spiral surface. They are rare in the Maestrichtian-Campanian.

\section{Nuttallinella? sp.}

(Plate 2, Figs. 7, 8; Plate 4, Figs. 1-4)

The spiral surface varies from markedly concave, suggesting attachment, to slightly convex but is typically planar. The relative diameter of the final whorl and the flare of its periphery also vary widely. However, the blunt, almost truncate summit of the cone with its deep umbilicus and incised, converging sutures gives a distinctive planoconvexity to the species. The low interiomarginal aperture is bent posteriorly near the peripheral margin in the manner of Nuttallinella, but the internal plate of that genus was not seen.

This species appears to be the same as Globorotalites conicus (Carsey) Beckmann $(1978$, pl. 4, figs. 22, 23) but not the same as Globorotalites conicus (Carsey) Sliter (1977b, pl. 9, figs. 7, 8). None of the three above is Globorotalites conicus (Carsey), which is a large, stable, smooth-surfaced, deeply umbilicate, bullet-shaped form, of exactly the properties illustrated by Plummer (1931, pl. 14, fig. 11a, b). Nuttallinella? sp. is similar to Globorotalia subconica Morrow, which may be gradational into Globorotalia umbilicata Loetterle, but the presence of a nuttalline apertural bend remains to be demonstrated for those two species.

Nuttallinella? sp. is persistent and at some horizons is common in the Santonian-Coniacian.

\section{Nuttallinella? spinea (Cushman)}

(Plate 4, Figs. 5-7)

Truncatulina spinea Cushman, 1926, p. 22, fig. 10a-c.

Globorotalites spineus (Cushman) Sliter, 1968, p. 119, pl. 22, fig.

4a-c; 1977b, p. 692, pl. 11, fig. 8; Beckmann, 1978, p. 766, pl. 4, figs. 21, 27.

The spines are located opposite the intercameral sutures in the imperforate flange. The spiral surface is usually covered by a minutely granular deposit of secondary calcite. A definite umbilicus is usually covered by an extension of the final chamber. The interiomarginal aperture is very low in proximity to the peripheral keel, where it bends posteriorly in accordance with a bend in the aperture face. The slit-like aperture continues into the umbilicus along the edge of the extension of the final chamber.

The general form and the external aspect of the aperture are like those of Nuttallinella, but the internal plate was not observed. Except for the spines and the secondary deposit on the spiral surface, this species seems identical to $N$. florealis (Cushman).

This distinctive species is few but relatively persistent in the Maestrichtian-Campanian interval.

Osangularia popenoei (Trujillo)

(Plate 2, Fig. 9; Plate 4, Figs. 17-19)

Anomalina popenoei Trujillo, 1960, p. 335, pl. 48, fig. 9a-c.

It is difficult to understand the differences between $O$. popenoei, O. californica Dailey, O. insigna Dailey, and O. utatarensis (Sastri and Sastry). Scheibnerová (1974) has reported that $O$. californica is a junior synonym of $O$. utatarensis and noted variation in the periphery and umbonal plug of $O$. utatarensis from Leg 27 that would include Dailey's diagnostic properties of $O$. insigna.

Specimens from the Maestrichtian-Campanian of Hole 530A have a wall structure, or preservation, in which the camerae are very finely perforate and white in color; the periphery, sutures, and umbilical boss are nonperforate and translucently gray; and the aperture is clearly osangularine. Specimens from the Santonian-Coniacian are composed of light gray, translucent material entirely (possibly internal moulds); the intercameral sutures are broad and elevated, and the aperture is not clearly osangularine; in fact, it appears on some specimens to be an arched, interiomarginal opening near the periphery, possibly with a slight lip. These specimens have been assigned to $O$. popenoei but seem closer to $O$. utatarensis as it has been presented by Scheibnerová.

The first morphotype described above is extremely rare in a few residues from the lower part of the Maestrichtian-Campanian, and 
the second type occurs at several horizons of the Santonian-Coniacian in rare to few frequency.

\section{Pleurostomella obtusa Berthelin}

(Plate 3, Figs. 14-17)

Pleurostomella obtusa Berthelin, 1880, p. 29, pl. 1, fig. 9.

Pleurostomella reussi Berthelin, 1880, p. 28, pl. 1, figs. 11, 12, not fig. 10.

Pleurostomella obtusa has been reported to be the senior synonym and megalospheric form of $P$. reussi Berthelin (Bartenstein, 1954, p. 41; Moullade, 1966, p. 63). Specimens of $P$. obtusa from Hole 530A are broken or only partially developed. They are rare to few, but persistent in the Albian.

\section{Pseudoclavulina gaultina carinata (Neagu)}

$$
\text { (Plate 1, Fig. 8) }
$$

Clavulinoides gaultinus carinata Neagu, 1962 , pp. 420,421 , pl. 40 , figs. 14-20.

Most specimens of Pseudoclavulina gaultina (Morozova) encountered in Hole 530A belong to the carinata variety, which has been confused with Clavulina gabonica Le Calvez et al. The latter lacks the prominent sutural depression and chamber shape of the uniserial stage that marks carinata, but C. gabonica is similar to and may be a junior synonym of $P$. gaultina intermedius (Neagu).

Pseudoclavulina gaultina carinata, which is one of the most persistent, widespread, deep-water benthic forms of the medial Cretaceous, is a distinctive, conspicuous, and recurrent species of the ?lower Turonian and Albian intervals of Hole 530A.

\section{Pullenia coryelli White}

Pullenia coryelli White, 1929 , p. 56 , pl. 5, fig. 22a, b.

Specimens are rare and erratic in occurrence in the MaestrichtianCampanian interval. The interpretation of them as indigenous forms herein may be erroneous.

\section{Reussella szajnochae (Grzybowski)} (Plate 2, Fig. 1)

Verneuilina szajnochae Grzybowski, 1896, p. 287, pl. 9, fig. 19.

This distinctive species is, like Aragonia ouezzanensis, a rare but persistent member of the Maestrichtian-Campanian fauna.

\section{Spiroplectammina chicoana Lalicker}

(Plate 1, Figs. 3, 4)

Spiroplectammina chicoana Lalicker, 1935, p. 7, pl. 1, figs. 8, 9; Beckmann, 1978, p. 769, pl. 1, fig. 3. terval.

Uncommon to rare but persistent in the Santonian-Coniacian in-

\section{Spiroplectammina dentata (Alth)}

(Plate 1, Fig. 5)

Textularia dentata Alth, 1850 , p. 262, pl. 13, fig. 13.

Rare to uncommon but persistent in the Maestrichtian-Campanian interval. Often well preserved.

\section{Spiroplectammina grzybowski Frizzell}

(Plate 1, Fig. 6)

Spiroplectammina grzybowski Frizzell, 1943, p. 339, pl. 12, fig. 12a-b, 13.

Having seen specimens of Bolivinopsis rosula (Ehrenberg) Cushman (1946, pl. 44, figs. 5-8) from the Gulf Coastal Plain, I am impressed with the difference between its test and that of Spiroplectammina grzybowski Frizzell from Hole 530A. The latter is finely but definitely agglutinated and seemingly identical to Frizzell's holotype, whereas the former is much more calcitic, glassy, and similar to $B$. capitata Yakelov, the holotype of Bolivinopsis. Consequently, utilization of Spiroplectammina seems advisable herein.

The form of Frizzell's holotype and paratype appears to be identical with that of Spiroplecta spectabilis Grzybowski 1898 and S. clotho Grzybowski 1901 respectively, and it is evident that he considered the relative size of the planispiral portion of these tests an intraspecific variant, as does Hanzliková (1972, p. 48), who has synonymized spectabilis and clotho. Hanzliková has also placed grzybowski in synon- ymy with these two, but her assignment of them to Bolivinopsis reopens the question of the composition of Grzybowski's species. If it is that of Bolivinopsis, they are not synonymous with Frizzell's species.

Spiroplectammina grzybowski Frizzell occurs as rare and broken specimens in several samples from the Maestrichtian of Hole 530A. They may be displaced.

Textularia sp.

(Plate 1, Figs. 1, 2; Plate 3, Figs. 1, 2)

This species is similar to Spiroplectammina roemer Lalicker (Textularia laevis Roemer), except for greater curvature of chambers and a distinct proloculus instead of a coil. It has the shape and chamber curvature of $S$. senonian Lalicker but again lacks the spiral stage.

Textularia sp. is rare in the Albian interval.

\section{Valvulineria spp.}

(Plate 3, Figs. 21-23)

Tiny, variable, poorly preserved Valvulineria of the $V$. parva Khan to $V$. praestans Magniez-Jannin morphic group are rare in the Albian but could not be identified specifically.

\section{Valvulineria? vombensis (Brotzen)}

(Plate 2, Fig. 6; Plate 3, Figs. 24-26)

Pseudovalvulineria vombensis Brotzen, 1945, p. 50, pl. 1, figs. 12, 13. ?Gavelinella whitei (Martin) Sliter, 1968, p. 126, pl. 24, fig. 1a-c; Hanzliková, 1972, p. 133, pl. 38, fig. 5a-c; pl. 39, fig. 9a-c.

The rare specimens of this assignment differ from the primary definition of the species by having in the circumumbilical area very thick and raised but relatively straight sutures (see Brotzen, 1945, p. 51, text-fig. 9), and coarsened, closely packed, coalesced mural pores and large depressions in the intersutural areas, and a large umbilical flap.

Extremely rare in the lower Campanian of Hole 530A.

\section{Valvulineria? whitei (Martin)}

(Plate 3, Figs. 27, 28)

Anomalina whitei Martin, 1964, p. 106, pl. 16, figs. 4a-c. ?Rotalia beccariiformis White, 1928, p. 287, pl. 39, figs. 2a-c. ?Rotalia beccariiformis, var. White, 1928, pl. 39, figs. 3a-c. ?Rotalia beccariiformis, var. White, 1928, pl. 39, figs. 4a-c. Gavelinella whitei (Martin) Sliter, 1977, p. 695, pl. 13, figs. 2-5. Gavelinella beccariiformis (White) Beckmann, 1978, p. 766, pl. 5, figs. 1,2 .

Gavelinella beccariiformis (White), conical variety Beckmann, pl. 5, fig. 3.

The distinctive properties of this species occur in the umbilical region, where the sutures become widened, elevated, and irregular in outline and topography; where the mural pores become large, irregular in shape, and coalesced; where, in consequence of the last, irregular depressions and meandering, branching grooves occur between the sutures and may connect with the umbilicus. The aperture is a low, interiomarginal opening that extends along the umbilical half of the apertural face and continues along the umbilical margin of the final, if not other, chambers. Some specimens appear to have the remnant of an umbilical flap. It appears that the apertural function was concentrated in the umbilicus and extended into the adjacent area of pits, grooves, etc. The shape varies considerably, with the result that highly vaulted forms occur, as Beckmann has noted (see above), but the prevalent form is roundly biconvex, trochospiral with a very low angle of coiling. The combination of typical form and apertural properties have led to the assignment to Valvulineria? employed herein.

In addition to the question of generic affinities, there are problems of nomenclature which involve priority, synonymy, and consanguinity. First, there is the question of whether White's variations are of one species. It would seem that they are, but he did distinguish $R$. beccariiformis by beaded sutures, which have not been specifically mentioned since and do not occur in material from Hole 530A; and he did, by his wording, imply that the "thread-like lines" are sutural in position, rather than intersutural. The second question is the status of Pseudovalvulineria vombensis Brotzen and Anomalina whitei Martin, both of which were specifically synonymized with and do appear to be the same as White's varieties of $R$. beccariiformis. White's material was from what would seem to have been a tropic realm, in contrast to 
the evidently higher latitudinal position of the Brotzen and Martin taxa; consequently, it seems prudent to retain one or both of them. Of these two, Brotzen's species has priority, but there are some peculiarities of definition, particularly the nontypic illustrations (Brotzen, 1945 , text figs. 9, 1-4, p. 51), wherein the circumumbilical topography includes very thick and raised but rather straight sutures and intersutural areas without meandering depressions. Brotzen noted that his specimens from the Maestrichtian and Campanian are closer to White's varieties than are his specimens from the Santonian and Coniacian; perhaps the specimens of text-figure 9 are older.

Without arguing the case, I shall maintain $R$. beccariiformis White, $P$. vombensis Brotzen (for forms of his text-fig. 9), and $A$. whitei. Until typic or topotypic material can be compared, change in nomenclature is as likely to be wrong as to be right.

\section{ACKNOWLEDGMENTS}

It is a pleasure to thank the Deep Sea Drilling Project for the opportunity to sail on Leg 75 and the University of Texas at Arlington for leave to do so. The Department of Geology of the university provided the many facilities necessary for the shore-based work, and my wife worked extensively as technician, typist, etc. For critical reading of the manuscript I am indebted to Peter R. Thompson, Geological Research Group, ARCO Oil and Gas Company, Plano, Texas, and to Frank P. van Morkhoven, Shell Development Company, Houston, Texas.

\section{REFERENCES}

Alth, A., 1850. Geognostiche-palaeontologische Beischreibung der nächsten Umgebung von Lemberg. Haidinger's Naturw. Abh. 3(2): 1-262, pl. 1-13.

Bartenstein, H., 1954. Revision von Berthelin's Memoire 1880 über die Alb-Foraminiferen von Montcley. Senck. Leth., 35(1/2): $37-50$, pl. 1.

Bartenstein, and Bolli, H. M., 1973. Die Foraminiferen der Unterkreide von Trinidad, W. I. Dritter Teil: Maridaleformation (Co-Typlokalität). Eclog. Geol. Helv., 66(2):389-418, pl. 1-6.

Beckmann, J. P., 1978. Late Cretaceous smaller benthic foraminifers from Sites 363 and 364 DSDP Leg 40, southeast Atlantic Ocean. In Bolli, H. M., Ryan, W. B. F., et al., Init. Repts. DSDP, 40: Washington (U.S. Govt. Printing Office), 759-781, pl. 1-5.

Beckmann, J. P., and Koch, W., 1964. Vergleiche von Bolivinoides, Aragonia und Tappanina (Foraminifera) aus Trinidad (Westindien) und Mitteleuropa. Geol. Jahrb. 83:31-64, pl. 5-7.

Belford, D. J., 1960. Upper Cretaceous Foraminifera from the Toolonga Calcilutite and Gingin Chalk, Western Australia. Aust. Bur. Miner. Resour. Géol. Geophys., 57:1-198, pl. 1-35.

Berthelin, G., 1880. Mémoire sur les Foraminifères fossiles de l'Étage Albien de Montcley. Soc. Geol. Fr. Ser. 3, Mem., 1(5):1-84, pl. $1-4$.

Brotzen, F., 1945. De geologiska resultaten fran borrningarna vid Höllviken. Sver. Geol. Unders., 38(7): 1-64, pl. 1-4.

Carbonnier, A., 1952. Sur un gisement de foraminiferes d'age Cenomanien supérieure de la région de Taza (Maroc). Soc. Geol. Fr. Bull., Ser. 6, 2(1-3):111-122, pl. 5-7.

Caron, M., 1978. Cretaceous planktonic foraminifers from DSDP Leg 40, southeastern Atlantic Ocean. In Bolli, H. M., Ryan, W. B. F., et al., Init. Repts. DSDP, 40: Washington (U.S. Govt. Printing Office), 651-678, pl. 1-11.

Cushman, J. A., 1926. Some Foraminifera from the Mendez shale of eastern Mexico. Cushman Lab. Foraminiferal Res., Contrib. 2 (1):16-26, pl. 2-3.

1946. Upper Cretaceous Foraminifera of the Gulf coastal region of the United States and adjacent areas. U.S. Geol. Surv., Prof. Pap., 206:1-241, pl. 1-66.

Cushman, and Church, C. C., 1929. Some Upper Cretaceous Foraminifera from near Coalinga, California. Proc. Calif. Acad. Sci., Ser. 4, 18:497-530.

Cushman, and Renz, H. H., 1946. The foraminiferal fauna of the Lizard Springs Formation of Trinidad, British West Indies. Cushman Lab. Foraminiferal. Res., Spec. Publ., 18:1-48, pl. 1-8.

Dam, A. ten, 1947. Sur quelques espèces nouvelles ou peu connue dans le Crétacé inférieur (Albien) des Pays-Bas. Geol. Mijnbouw, 8:25-29.
Douglas, R. G., 1973. Benthonic foraminiferal biostratigraphy in the central North Pacific, Leg 17, Deep Sea Drilling Project. In Winterer, E. L., Ewing, J. I., et al., Init. Repts. DSDP, 17: Washington (U.S. Govt. Printing Office), 607-673, pl. 1-25.

Eicher, D. L., and Worstell, P., 1970. Cenomanian and Turonian Foraminifera from the Great Plains, United States. Micropalentology, 16(3):269-364, pl. 1-13.

Frizzell, D. L., 1943. Upper Cretaceous Foraminifera from Peru. $J$. Paleontol., 17(4):331-353, pl. 55-57.

Gandolfi, R., 1942. Ricerche micropaleontologiche e stratigrafiche sulla Scaglia e sul Flysch Cretacici dei dintorni di Balerna (Canton Ticino). Riv. Ital. Paleontol., 20:1-158, pl. 1-13.

Grzybowski, J., 1896. Foraminifera of the red clay of Wadowice. Pol. Akad. Sci., Krakow, Ser. 2, 10:261-308, pl. 8-11.

Hanzlikova, E., 1972. Carpathian Upper Cretaceous Foraminiferida of Moravia. Ustred. Ustav. Geol. Rozpr., 39:1-160, pl. 1-40.

Keller, B. M., 1935. Mikrofauna der Oberen Kreide des Dniepr-Donez Beckens, und einiger angrenzender Gebiete. Soc. Nat. Sci. Moscow, Bull. n.s., 43 (Sec. Geol., 13[4]):552, 558, pl. 3, fig. 25-27.

Krasheninnikov, V. A., 1973. Cretaceous benthonic Foraminifera, Leg 20, Deep Sea Drilling Project. In Heezen, B. C., MacGregor, I. D., et al., Init. Repts. DSDP, 20: Washington (U.S. Govt. Printing Office), 205-219, pl. 1-3.

1974. Upper Cretaceous benthonic agglutinated Foraminifera, Leg 27 of the Deep Sea Drilling Project. In Veevers, J. J., Heirtzler, J. R., et al., Init. Repts. DSDP, 27: Washington (U.S. Govt. Printing Office), 631-661, pl. 1-7.

Lalicker, C. G., 1935. New Cretaceous Textulariidae. Cushman Lab. Foram. Res. Contrib., 11(1):1-12, pl. 1-2.

Loeblich, A. R., Jr., and Tappan, H. N., 1963. Sarcodina, chiefly "Thecoambians" and Foraminiferida, Protista 2. In Moore, R. C. (Ed.), Treatise on Paleontology, Part C. Geol. Soc. Am., 1-900, fig. 1-653.

Luterbacher, H. P., 1975. Early Cretaceous Foraminifera from the northwestern Pacific: Leg 32 of the Deep Sea Drilling Project. In Larson, R. L., Moberly, R., et al., Init. Repts. DSDP, 32: Washington (U.S. Govt. Printing Office), 703-718, pl. 1-5.

McNulty, C. L., 1976. Cretaceous foraminiferal stratigraphy, DSDP Leg 33, Holes 315A, 316 and 317A. In Schlanger, S. O., Jackson, E. D., et al., Init. Repts. DSDP, 33: Washington (U.S. Govt. Printing Office), 369-381, pl. 1-3.

Malapris, M., 1965. Les Gavelinellidae et formes affines du gisement Albien de Courcelles (Aube). Rev. Micropaleontol., 8(3):131-150, pl. 1-5.

Marsson, T., 1878. Die Foraminiferen der weissen Schreibkreide der Insel Rugen. Mitt. natur. Verein. Neu-Vorpommern und Rügen, 10:115-196, pl. 1-5.

Martin, L., 1964. Upper Cretaceous and Lower Tertiary Foraminifera from Fresno County, California. Geol. Bundesanst., Jahrb., Sonderbd., 9:1-128.

Moullade, M., 1966. Etude stratigraphique et micropaleontologique du Crétacé Inférieur de la "Fosse Voncontienne." Doc. Lab. Geol. Fac. Sci. Lyon, 15:1-369, pl. 1-17.

Neagu, T., 1962. Clavinulinoides gaultinus (Morozova, 1948) in the Cretaceous Flysch in Roumania. Pol. Geol. Soc. Ann., 32(3): 415-426.

Plummer, H. J., 1931. Some Cretaceous Foraminifera in Texas. Univ. Texas Bull., 3101:109-203, pl. 8-15.

Porthault, B., 1974. Le Crétacé Superieur de la "Fosse Vocontienne" et des regiones limitrophes (France-Sud-Est) [Thése]. Université Claude-Bernard, Lyon.

Premoli Silva, I., and Boersma, A., 1977. Crétacéous planktonic foraminifers-DSDP Leg 39 (South Atlantic). In Supko, P. R., PerchNielsen, K., et al., Init. Repts. DSDP, 39: Washington (U.S. Govt. Printing Office), 615-641, pl. 1-2.

Proto Decima, F., and Bolli, H. M., 1978. Southeast Atlantic DSDP Leg 40 Paleogene benthonic foraminifers. In Bolli, H. M., Ryan, W. B. F., et al., Init. Repts. DSDP, 40: Washington (U.S. Govt. Printing Office), 783-809.

Reuss, A. E., 1860. Die Foraminiferen der Westphàlischen Kreideformation. Kais. Akad. Wissens. Wien, Math.-Naturw. Cl., Sitzungsb., 40:147-237, pl. 1-13.

1862. Palaeontologische Beitrage, II, III. Kais. Akad. Wissens. Wien, Math.-Naturw. Cl., Sitzungsb., 44:304-342, pl. 1-8. 
1863. Die Foraminiferen des norddeutschen Hils und Gault. Kais. Akad. Wissens. Wien, Math.-Naturw. Cl., Sitzungsb., 46(1): 5-100, pl. 1-13.

Rey, M., 1954. Description des quelques espèces nouvelles de foraminifères dans le Nummulitique Nord-Marocain. Bull. Soc. Géol. Fr., Ser. 6, 4:209-211.

Robaszynski, F., and Caron, M. (Eds.), 1979. Atlas de Foraminifères planctoniques du Crétacé Moyen (Mer Boreale et Téthys), I, II. Cahiers de Micropaléont., 1:1-185, pl. 1-39; 2:1-181, pl. 40-80.

Saccal, V., and Debourle, A., 1957. Foraminiferes d'Aquitaine, 2nd Part: Peneroplidae à Victoriellidae. Soc. Géol. Fr. Mem. 78, n.s., $36(1): 1-88$, pl. 1-35.

Scheibnerová, V., 1973. A comparison of the austral and boreal Lower Cretaceous foraminiferal and ostracodal assemblages. In Casey, R., and Rawson, P. F. (Eds.), The Boreal Lower Cretaceous: Liverpool (Seal House Press), pp. 407-414.

1974. Aptian-Albian benthonic Foraminifera from DSDP Leg 27, Sites 259, 260, and 263, eastern Indian Ocean. In Veevers, J. J., Heirtzler, J. R., et al., Init. Repts. DSDP, 27: Washington (U.S. Govt. Printing Office), 697-743, pl. 1-11.

1978. Aptian and Albian benthic foraminifers of Leg 40, Sites 363 and 364, southern Atlantic. In Bolli, H. M., Ryan, W. B. F., et al., Init. Repts. DSDP, 40: Washington (U.S. Govt. Printing Office), 741-757, pl. 1-4.

Sigal, J., 1969. Contribution à une monographie des rosalines. 2. L'espèce Rotalipora appenninica (O. Renz, 1936), origine phylétique et taxonomie. Proc. First Int. Conf. Planktonic Microfossils, 2: 622-639, pl. 1-2.

Sliter, W. V., 1968. Upper Cretaceous Foraminifera from southern California and northwestern Baja California, Mexico. Univ. Kansas Paleontol. Contrib., 49(art. 7):1-141, pl. 1-24.

1977a. Cretaceous foraminifers from the southwestern Atlantic Ocean, Leg 36, Deep Sea Drilling Project. In Barker, P. F., Dalziel, I. W. D., et al., Init. Repts. DSDP, 36: Washington (U.S. Govt. Printing Office), 519-573, pl. 1-14.

1977b. Cretaceous benthic foraminifers from the western South Atlantic Leg 39, Deep Sea Drilling Project. In Supko, P. R., Perch-Nielsen, K., et al., Init. Repts. DSDP, 39: Washington (U.S. Govt. Printing Office), 657-697.

Trujillo, E. F., 1960. Upper Cretaceous Foraminifera from near Redding, Shasta County, California. J. Paleontol., 34(2):290-346, pl. 43-50.

van Morkhoven, F. P. C. M., 1981. Cosmopolitan Tertiary bathyal benthic Foraminifera. Gulf Coast Assoc. Geol. Soc., Suppl. Trans., 31:445. (Abstract)

White, M. P., 1928-1929. Some index Foraminifera from the Tampico Embayment area of Mexico. J. Paleontol, 2(3):177-215, pl. 27-29; 2(4):280-316, pl. 38-42;3(1): 30-58, pl. 4-5.

Date of Initial Receipt: October 6, 1982 


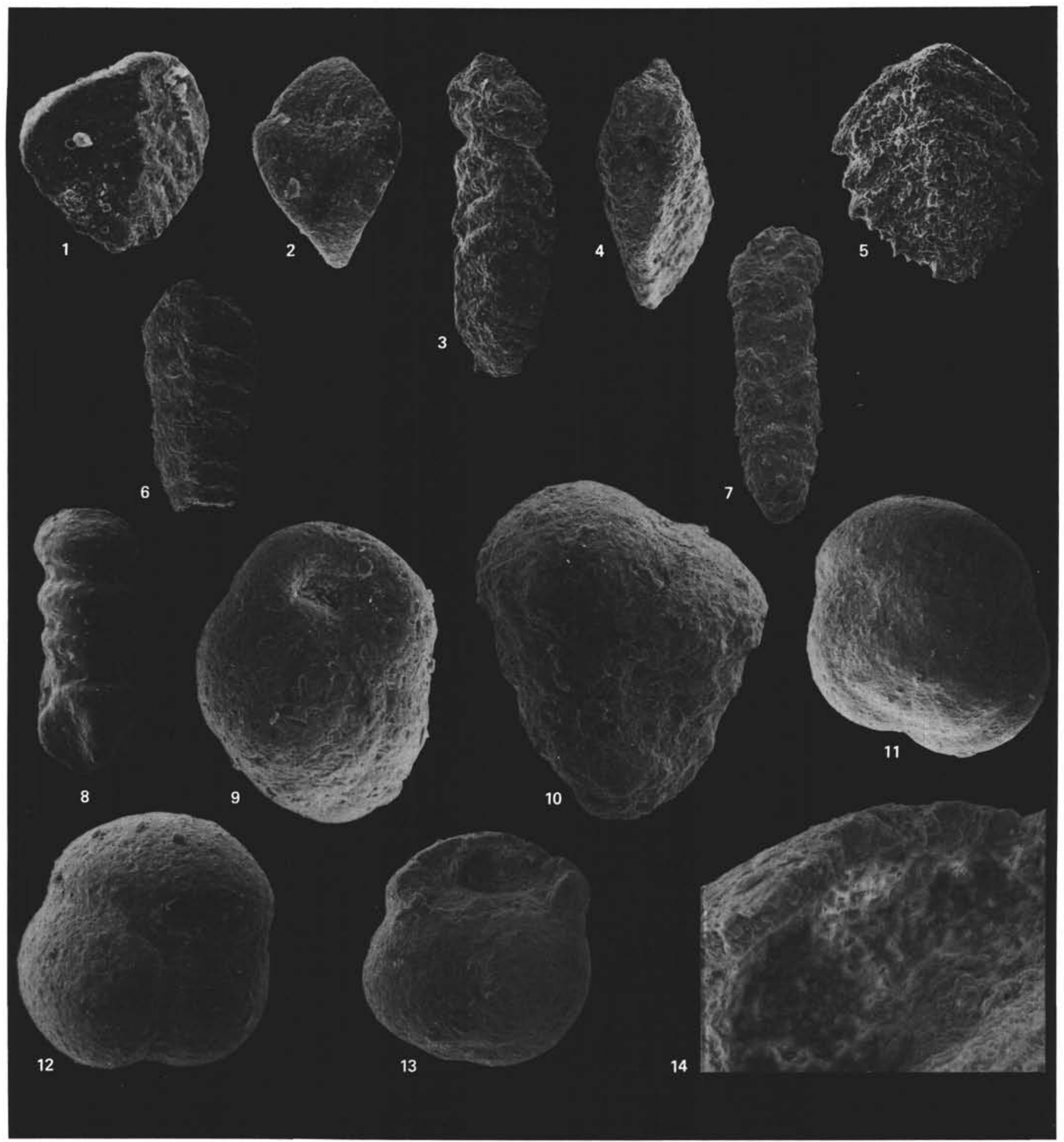

Plate 1. Cretaceous foraminifers. 1-2. Textularia sp., planar and apertural views; max. dimen. 0.35 mm; Sample 530A-101,CC. 3-4. Spiroplectammina chicoana Lalicker, planar and apertural views; max. dimen. $0.80 \mathrm{~mm}$; Sample 530A-88,CC. 5. Spiroplectammina dentata (Alth), planar view; max. dimen. $0.57 \mathrm{~mm}$; Sample $520 \mathrm{~A}-79-4,74-75 \mathrm{~cm}$. 6. Spiroplectammina grzybowski Frizzell, planar view; max. dimen. 0.40 $\mathrm{mm}$; Sample 530A-50-4, 18-22 cm. 7. Dorothia filiformis (Berthelin)?, planar view; max. dimen. $0.65 \mathrm{~mm}$; Sample 530A-93-3, 59-60 cm. 8. Pseudoclavulina gaultina carinata (Neagu), planar view; max. dimen. $0.88 \mathrm{~mm}$; Sample 530A-100,CC. 9. Arenobulimina sp., oblique view; max. dimen. $0.40 \mathrm{~mm}$; Sample 530A-103-4, 53-55 cm. 10. Dorothia gradata (Berthelin)?, planar view; max. dimen. 0.49 mm; Sample 530A103-4, 53-55 cm. 11-14. Ammosphaeroidina sp., (11-12) spiral and umbilical views; max. dimen. 0.48 mm; Sample 530A-103-2, 88-90 cm; (13-14) wall structure of broken specimen; max. dimen. $0.50 \mathrm{~mm}$; Sample 530A-101,CC. 


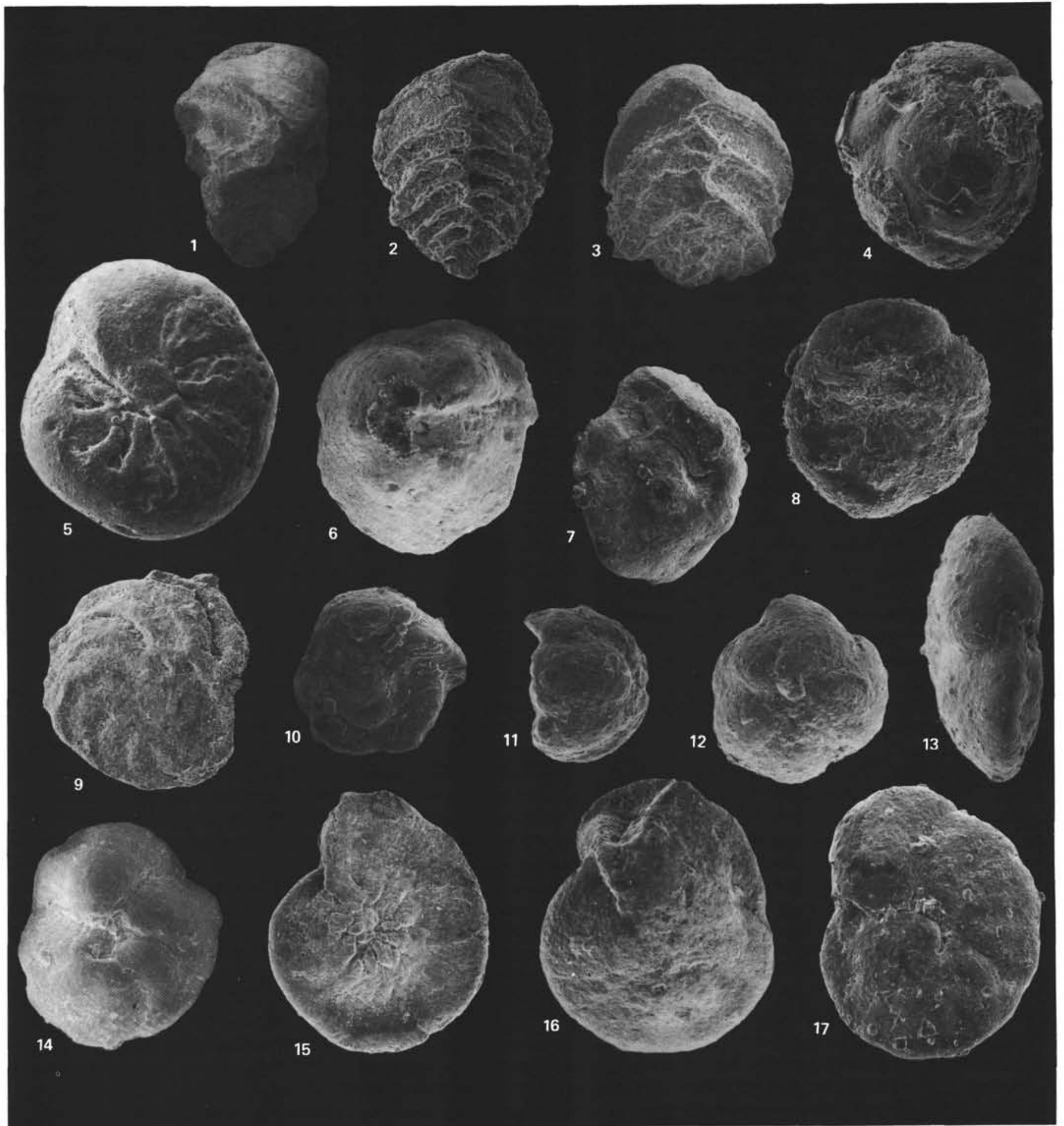

Plate 2. Cretaceous foraminifers. 1. Reussella szajnochae (Grzybowski), planar view; max. dimen. 0.62 mm; Sample 530A-62-3, 49-51 cm. 2. Aragonia materna kugleri Beckmann and Koch, planar view; max. dimen. $0.32 \mathrm{~mm}$; Sample 530A-85-3, 138-140 cm. 3. Aragonia ouezzanensis (Rey), planar view; max. dimen. $0.29 \mathrm{~mm}$; Sample 530A-63-2, 77-79 cm. 4-5. ?Conorbina newtoni (Eicher and Worstell), spiral and umbilical views; max. dimen. $0.37 \mathrm{~mm}$; Sample 530A-93-3, 59-60 cm. 6. Valvulineria? vombensis (Brotzen), umbilical view; max. dimen. $0.69 \mathrm{~mm}$; Sample 530A-51-2, 62-64 cm. 7-8. Nuttallinella? sp., umbilical and oblique umbilical views; max. dimen. $0.32 \mathrm{~mm}, 0.28 \mathrm{~mm}$; Sample 530A-88,CC. 9. Osangularia popenoei (Trujillo), spiral view; max. dimen. 0.32 mm; Sample 530A-79-4, 74-75 cm. 10-12. Gyroidina quadrata Cushman and Church, spiral, umbilical, and peripheral views; max. dimen. $0.22 \mathrm{~mm}$; Sample 530A-95-3, 135-316 cm. 13. Gavelinella umbonella (Reuss), umbilical view; max. dimen. $0.45 \mathrm{~mm}$; Sample 530A-95-2, 9-10 cm. 14-15. Lingulogavelinella sp., ventral and dorsal views; (14) max. dimen. $0.56 \mathrm{~mm}$; (15) max. dimen. $0.49 \mathrm{~mm}$; Sample $530 \mathrm{~A}-103-2,88-90 \mathrm{~cm}$. 16-17. Gavelinella berthelini (Keller), ventral and peripheral views of sinistral specimen; max. dimen. $0.62 \mathrm{~mm}$; Sample 530A-94-1, 142-148 cm. 


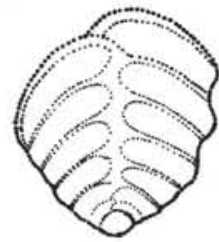

1
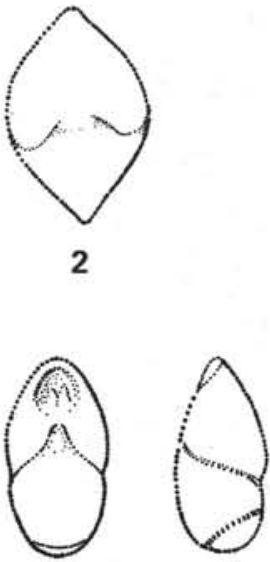

14

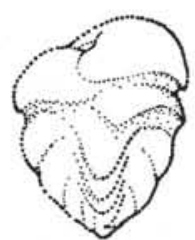

3

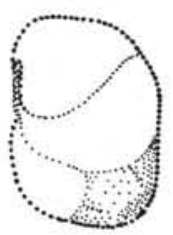

5

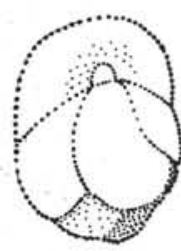

6

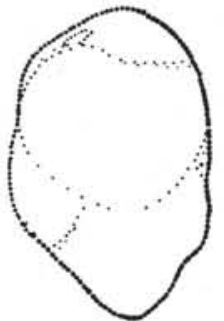

7

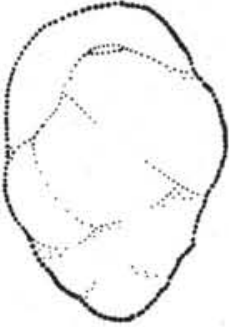

8

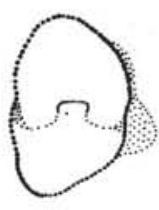

4

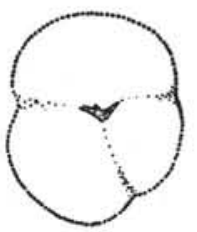

9

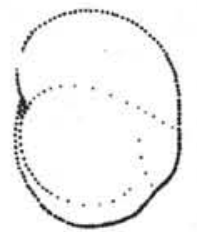

10

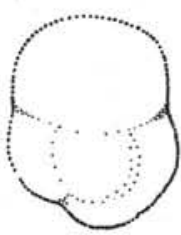

11

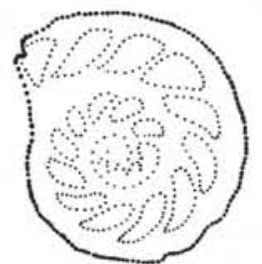

12

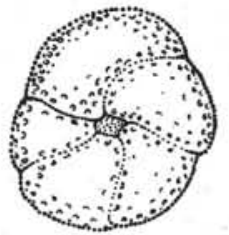

18

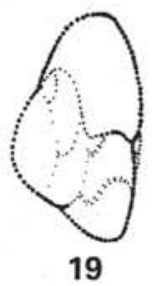

19

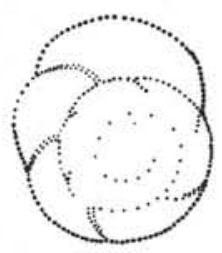

20

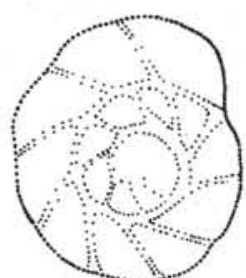

24

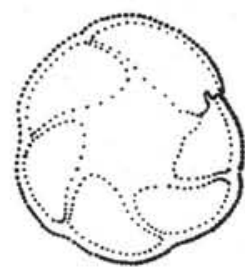

29

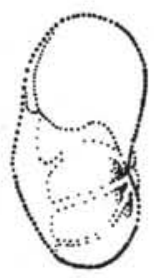

25

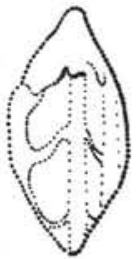

30

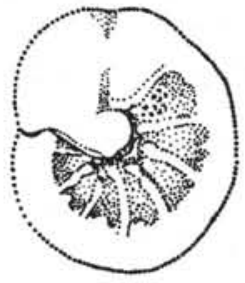

26

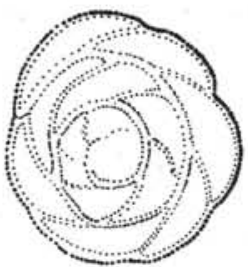

31

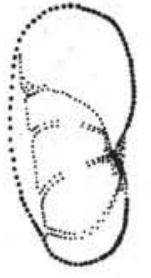

27

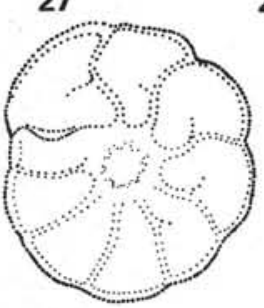

32

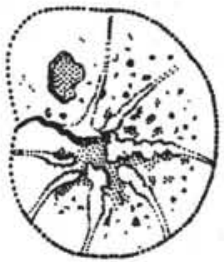

28

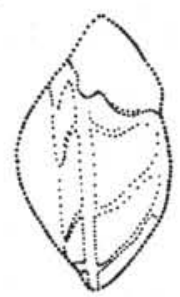

33

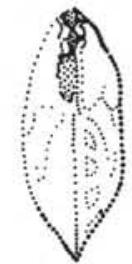

13

Plate 3. Cretaceous foraminifers. 1-2. Textularia sp., planar and apertural views; max. dimen. 0.35 mm; Sample 530A-101,CC. 3-4. Gaudryina pulvina Belford, planar and apertural views; max. dimen. $0.48 \mathrm{~mm}$; Sample 530A-77-2, 142-144 cm. 5-8. Arenobulimina sp.; (5-6) side and front views of common short form; max. dimen. $0.40 \mathrm{~mm} ;(7-8)$ side and front views of uncommon elongate form; max. dimen. $0.69 \mathrm{~mm}$; Sample 530A-103-4, 53-55 cm. 9-11. Ammosphaeroidina sp., umbilical, peripheral, and spiral views; max. dimen. 0.48 mm; Sample 530A-103-2, 88-90 cm. 12-13. Lenticulina velascoensis White, planar and peripheral views; max. dimen. $0.59 \mathrm{~mm}$; Sample 530A-55-1, 15-17 $\mathrm{cm}$. 14-17. Pleurostomella obtusa Berthelin, (14-15) oral and lateral views of juvenile; max. dimen. $0.62 \mathrm{~mm}$; (16-17) broken terminus of adult; max. dimen. $0.53 \mathrm{~mm}$; Sample 530A-101,CC. 18-20.?Conorbina newtoni (Eicher and Worstell), umbilical, peripheral, and spiral views; max. dimen. $0.37 \mathrm{~mm}$; Sample $530 \mathrm{~A}-93-3,59-60 \mathrm{~cm}$. 21-23. Valvulineria sp., spiral, umbilical, and peripheral views; max. dimen. $0.29 \mathrm{~mm}$; Sample 530A-103-2, 88-90 cm. 24-26. Valvulineria? vombensis (Brotzen), spiral, peripheral, and umbilical views; max. dimen. $0.61 \mathrm{~mm}$; Sample 530A-51-2, 62-64 cm. 27-28. Valvulineria? whitei (Martin), peripheral and umbilical views; max. dimen. 0.46 mm; Sample 530A-60,CC. 29-31. Nuttallides? sp., umbilical, peripheral, and spiral views; max. dimen. $0.48 \mathrm{~mm}$; Sample 530A-79,CC. 32-34. Nuttallides truempyi (Nuttall), umbilical, peripheral, and spiral views; max. dimen. $0.32 \mathrm{~mm}$; Sample 530A-54,CC. 


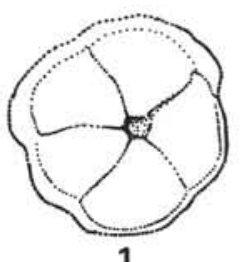

1

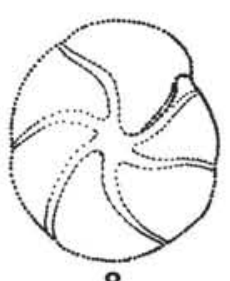

8

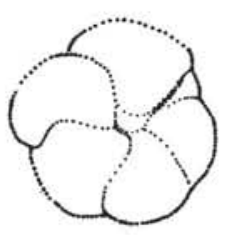

14

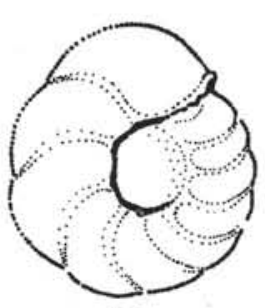

20

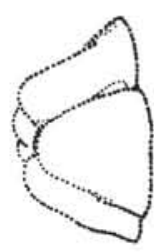

2

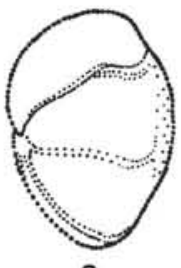

9

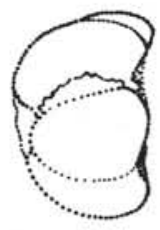

15

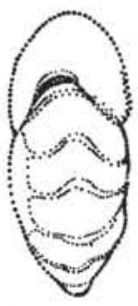

21

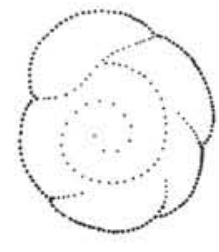

3

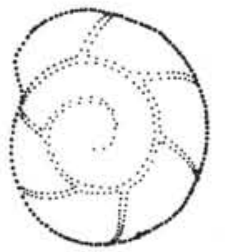

10

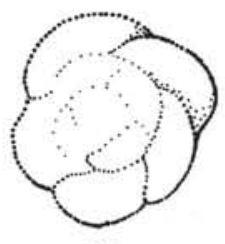

16

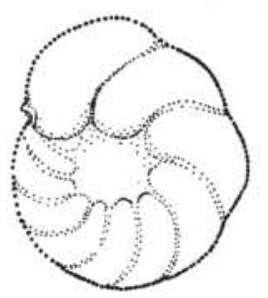

22

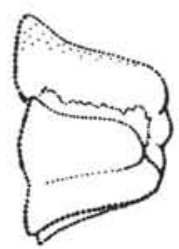

4

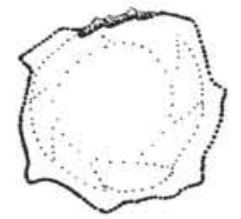

5

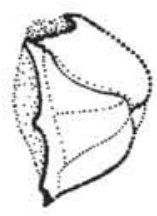

6

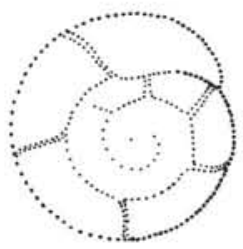

11

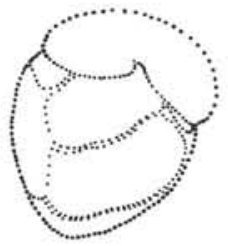

12

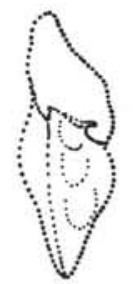

18
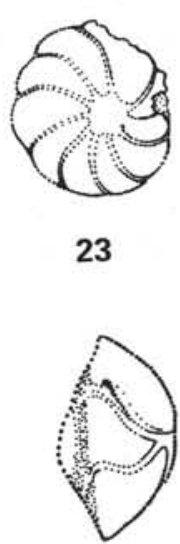

30
23

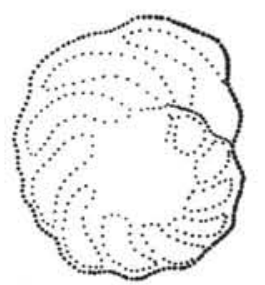

17

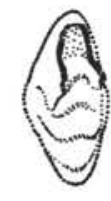

24

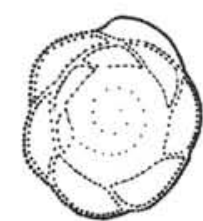

29

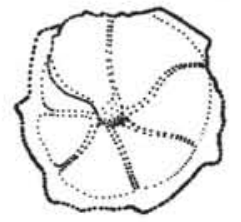

7

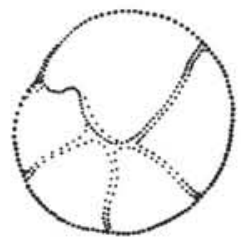

13

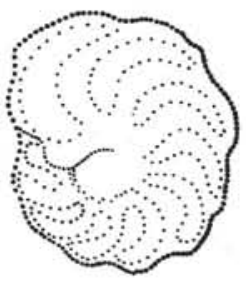

19

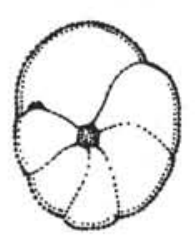

26

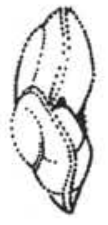

27

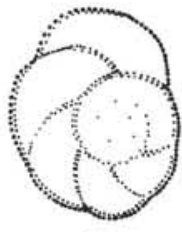

28

Plate 4. Cretaceous foraminifers 1-4. Nuttallinella? sp., (1-3) umbilical, peripheral, and spiral views of dextral specimen; max. dimen. 0.29 mm; (4) peripheral view of sinistral specimen; max. dimen. $0.32 \mathrm{~mm}$; Sample 530A-88,CC. 5-7. Nuttallinella? spinea (Cushman), spiral, peripheral, and umbilical views; max. dimen. 0.40 mm; Sample 530A-56-2, 70-72 cm. 8-10. Gyroidina diversus (Belford), umbilical, peripheral, and spiral views; max. dimen. $0.52 \mathrm{~mm}$; Sample 530A-68-5, 54-56 cm. 11-13. Gyroidina? mauretanica Carbonnier, spiral, peripheral, and umbilical views; max. dimen. $0.43 \mathrm{~mm}$; Sample 530A-103-4, 53-55 cm. 14-16. Gyroidina quadrata Cushman and Church, umbilical, peripheral, and spiral views; max. dimen. $0.24 \mathrm{~mm}$; Sample 530A-95-3, 135-136 cm. 17-19. Osangularia popenoei (Trujillo), spiral, peripheral, and umbilical views; max. dimen. $0.32 \mathrm{~mm}$; Sample 530A-79-4, 74-75 cm. 20-22. Gavelinella berthelini (Keller), ventral, peripheral, and dorsal views; max. dimen. 0.62 mm; Sample 530A-94-1, 142-148 cm. 23-25. Lingulogavelinella sp., dorsal, peripheral, and ventral views; max. dimen. $0.44 \mathrm{~mm}$; Sample 530A-103-2, 88-90 cm. 26-28. Gavelinella umbonella (Reuss), umbilical, peripheral, and spiral views; max. dimen. 0.45 mm; Sample 530A-95-2, 9-10 cm. 29-31. Charletonia sp., spiral, peripheral, and umbilical views; max. dimen. 0.43 mm; Sample 530A-60,CC. 32-34. Charletonia sp., spiral, peripheral, and umbilical views; max. dimen. $0.40 \mathrm{~mm}$; Sample 530A-60,CC. 